\title{
Packages or systems? Working capital management and financial performance among listed U.S. manufacturing firms
}

\section{Hakim Lyngstadaas ${ }^{1}$}

Accepted: 12 October 2020 / Published online: 7 November 2020

(C) The Author(s) 2020

\begin{abstract}
This study examines how working capital management packages (WCMPs) can lead to higher financial performance. This is done by exploring the formation, importance, and systematic interdependencies within and between WCMPs. The data set consists of 589 U.S. listed manufacturing firms that are being studied during the fiscal period 2012-2019. WCMPs are studied from both a package and a system approach. This is done by combining fuzzy set qualitative comparative analysis and panel data regression. In all, 11 effective WCMPs are found to be associated with high financial performance. Six of them constitute unique and empirically important packages and are also identified as systems. The findings can have consequences for managers and practitioners, as the study creates an explicit link between a firm's working capital management and financial performance.
\end{abstract}

Keywords Working capital management · Firm performance · fsQCA · Complementarity $\cdot$ Substitutive

\section{Introduction}

A key challenge within management accounting and control research is how to study complicated systems from a holistic perspective (Gerdin and Greve 2004). A common approach is to reduce the complicated system into manageable and separate parts, which are treated as being independent of each other and then studied (Gerdin and Greve 2004, 2008). However, such simplification warrants a reductionist critique, as the consequences can be a lack of a holistic understanding or model underspecification (Chenhall 2003; Granlund and Lukka 2017). Model underspecification can have severe consequences, such as spurious

Hakim Lyngstadaas

Hakim.lyngstadas@bi.no

1 BI Norwegian Business School, Trondheim, Norway 
results and wrong empirical interpretations. Furthermore, wrong empirical interpretations may also affect managerial decision making and control (Bedford and Malmi 2015).

The reductionist critique has not been properly mitigated in the working capital management (WCM) literature. WCM consists of several control components that are combined to constitute a system. This is based on how WCM entails 'the regulation, adjustment, and control of the balance of current assets and short-term liabilities of a firm such that maturing obligations are met, and the fixed assets are properly serviced' (Osisioma 1997, in Faden 2014). From a balance sheet perspective, WCM components consist of both current assets (as a part of total assets) and current liabilities (as a part of liabilities and shareholders' equity). However, empirical WCM research is often looked at either from the operational (henceforth termed 'OWC') or financial (henceforth termed 'FWC') perspective. The OWC perspective typically looks at working capital components such as inventory, accounts receivable, and accounts payable (see for instance Deloof 2003; García-Teruel and Martínez-Solano 2007; Baños-Caballero et al. 2012; Kroes and Manikas 2014; Amr Ahmed 2019). The FWC perspective commonly looks at working capital components such as cash and short-term investments (see for instance Gamba and Triantis 2008; Kim and Bettis 2014; Nason and Patel 2016; Bates et al. 2018; Martínez-Sola et al. 2018; Maurizio La 2019).

There are two different ways of understanding and exploring the relationship between components in a holistic perspective (Malmi and Brown 2008; Grabner and Moers 2013): a package approach or a system approach. A package is a configuration of components, while a system is a package that systematically relates to one another in a complementary or substitutive manner. This means that a system is also a package, while a package is not necessarily a system (Malmi and Brown 2008; Grabner and Moers 2013). This means that the various components constituting WCM can each be viewed as a package, but also form an interdependent system.

If there exists a system, then it is necessary to assess whether the system acts in a complementary or substitutive manner. A complementary relationship is said to exist if the level of the marginal benefit of each variable increases to the level of the other variable (Siggelkow 2002). For instance, the marginal benefit of holding more/ less inventory increases with the holding of more/less cash. A firm may hold more cash and inventory as a buffer against a future increase in demand or to absorb supply shocks (Bates et al. 2009). A substitutive relationship exists if the marginal benefit of each variable decreases in the level of the other variable (Siggelkow 2002), for instance, if a firm keeps higher levels of inventory and this leads to decreased levels of cash holding. The reason may be that they are competing for the same capital allocation, or the marginal cost of holding them both at a high level exceeds their marginal benefit (Fazzari and Petersen 1993; Opler et al. 1999). This substitution logic has been partially confirmed in earlier studies (Mun and Jang 2015; Weinraub and Visscher 1998).

The first research question is about identifying whether there exist working capital management packages (WCMPs):

How do manufacturing firms combine operational working capital and financial working capital into effective WCMPs that contribute to financial performance? 
The package approach can only indicate patterns of the interrelationship between variables (Grabner and Moers 2013). It is not possible to say whether they are systematically interdependent in the formation of packages or not. As such, it is necessary to conduct a separate analysis to verify whether packages also constitute a system or not (Grabner and Moers 2013). ${ }^{1}$ From a research perspective, it is important to detect systematic interrelationships because considering only one variable that is related to another variable may lead to spurious findings (model underspecification) (Chenhall 2003). From a managerial perspective, it is important to know whether WCM components need to be seen as independent or interdependent in their decision-making and control processes.

The first research question can inform the subsequent analysis of the components in WCM that are most likely to form systems, so the results from the first research question are used for examining the second research question ${ }^{2}$ :

How is financial performance affected by systematic interdependencies existing within and between variables of $O W C$ and FWC in WCMPs?

This study uses financial statements from 589 listed North American manufacturing firms in the sample fiscal period between 2012 and 2019. The CRSP/Compustat database was used to obtain the financial statements. ${ }^{3}$ The choice of the period provides a contemporary view of WCM in manufacturing firms and also avoids the potential bias when running a fuzzy set Qualitative Comparative Analysis (fsQCA) that may be introduced by the global financial crisis that began in 2007-2008. The benefit of focusing on one sector at a time brings the benefit of the possibility of controlling sector-specific characteristics (Fresard 2010; Eroglu and Hofer 2011). For instance, the manufacturing sector is known to be capital intensive and operates in a highly uncertain environment (Kroes and Manikas 2014). This may require a different type of WCM than in other sectors such as the retail or service sector (Mun and Jang 2015). While the U.S. manufacturing sector is known to be highly competitive, ${ }^{4}$ a sound WCM can increase a firm's competitive capability and positively affect financial performance. This makes it necessary to know more about what effective WCM entails for manufacturing firms.

The effectiveness of WCMPs is studied in terms of contribution to financial performance. Financial performance is a common dependent variable in management accounting and control research, as most for-profit firms must ensure that economic

\footnotetext{
${ }^{1}$ Here, it is not possible to establish whether OWC and FWC are simultaneously or sequentially determined.

${ }^{2}$ The approach of studying packages before systems of interdependencies has been selected because there is little pre-existing knowledge of how OWC and FWC are formed into WCMPs for achieving higher financial performance. An alternative approach would have been to pre ante hypothesize and select the variables in OWC and FWC that should be systematically interdependent. However, such an approach would have been not only challenging but would be an even more reductionist approach. To the best of the authors' knowledge, this is the first study that combines a package and system approach to study working capital management.

${ }^{3}$ Wharton Research Data Services (WRDS) was used in this paper. This service and its data constitute valuable intellectual property and trade secrets of WRDS and/or its third-party suppliers.

${ }^{4}$ https://info.microsoft.com/rs/157-GQE-382/images/EN-US-CNTNT-Report-2019Manufacturing-Trend s.pdf.
} 
goals are met (Otley 2016). Financial performance is a multidimensional concept, and this paper sees financial performance from an accounting return dimension. Combs et al. (2005) suggest that the accounting return dimension could be further split into two distinct sub-dimensions: profitability and liquidity. This is also empirically verified by Hamann et al. (2013). Profitability measures the efficiency to utilize production factors to generate earnings, whereas cash flows measure the ability to meet financial obligations from current business operations (Hamann et al. 2013). Profitability is measured as return on assets (ROA), and net cash flow from operations is used as a measure of liquidity.

Hamann et al. (2013) also identify growth and stock market performance as two other and distinct dimensions of financial performance. However, these measures will not be included in the paper. The reason is that growth and stock market performance measure different dimensions of financial performance and may lead to interpretational difficulties. For instance, growth (such as sales growth) may come at the expense of profitability or vice versa. The consequence is that these two measures act in opposite directions, with different types of WCMPs being suitable whether a firm aims at affecting accounting return or sales growth. Another reason is that, from a theoretical perspective, stock market performance is somewhat ambiguously related to WCM. The following question then arises: Should a diversified investor be concerned about WCM in daily business operations? There are also many other factors related to stock market performance, such as ownership concentration, competitive intensity, and macroeconomic determinants. This makes it difficult to capture other relevant control variables in a sufficient manner.

Two different methods are used when examining the two research questions. As the first research question is highly exploratory, fsQCA is employed. The findings show 11 WCMPs that are associated with high financial performance. Out of the 11 WCMPs, six packages are found to be empirically important. The components in OWC and FWC are either found to be redundant or core conditions in a given WCMP, suggesting that no components are peripheral in their empirical importance (Fiss 2011). Out of the six components constituting WCM (inventory, accounts receivable, accounts payable etc.), accounts payable is the component that is identified only once as a core condition in the six WCMPs.

The firms belonging in the group of high financial performers have an average ROA of approximately $12 \%$. The average OWC is approximately $20.5 \%$, and the average $\mathrm{FWC}$ is $0 \%$. This is in contrast to the remaining data sample (excluding high performers), with the averages of 9\% ROA, 25\% OWC, and 0\% FWC. This indicates that the WCMPs in firms having high ROA have a different configuration of their OWC and FWC than others in the sample population.

The second research question is analysed by panel data regression. All six unique WCMPs are found to constitute a complementary system as well. This indicates that the components in each WCMP are not selected independently of each other, but rather bear systematic interdependencies. This implies that WCM must be seen as forming a holistic decision-making and control system.

This study makes three major contributions. First, it broadly contributes to empirical research on management accounting and control. WCM affects research themes and issues such as capital budgeting, resource allocation, and control systems. More 
specifically, the study recognizes WCM as a decision-making and control system that acts as a driver of financial performance. By using both a package and system approach, the study can gain a more nuanced understanding of the formation, importance, and interdependence among the components constituting WCM. It also builds on and extends empirical research on working capital management from a configurational perspective (Weinraub and Visscher 1998; Howorth and Westhead 2003; Karatzas et al. 2016; Talonpoika et al. 2016; Galeazzo and Furlan 2018; Kosmol et al. 2018). Secondly, by combining the methods, each method can benefit from the other's distinct strengths. While the methodological approach used in this paper is similar to that of Bedford et al. (2016), its novelty lies in using panel archival data instead of cross-sectional data. Panel data can add to the robustness of the results, as they control the firm characteristics and time-varying effects (Greckhamer et al. 2013). What is uncovered by combining these two approaches is that there no singular WCMP that is effective for all firms. Different configurations can be equally effective, and there also exist some systematic interdependences between WCM components. Lastly, the formation, importance, and interplay between OWC and FWC may provide managers and practitioners with the practical 'know-how' to derive financial benefits from sound WCM. As such, this study is highly practically oriented and relevant for managers and practitioners working with or in manufacturing firms.

The remainder of the paper is structured as follows: The first section briefly describes the relevant theory and literature on working capital from a package and system approach. The theoretical foundation is based on configurational theorizing. The next section describes the research framework. This entails a description of both fsQCA and the panel data regression procedure. fsQCA is used for answering the first research question, and panel data regression is used for examining the second research question. This structure follows from how the results in the fsQCA inform which systematic interrelationships should be explored in the second research question. The last section discusses the main results from the package and system approach, certain managerial implications, robustness tests and proffers suggestions for future research directions.

\section{Theory and literature review}

\subsection{Working capital management and configurational theorizing}

In this paper, the perception of WCM as a package is based on configurational theorizing. Configurational theorizing is based on the complexity theory that suggests that each variable in a configuration is possibly both interrelated and interdependent on other variables for contributing to the outcome. Changes are believed to be made in a stepwise and episodic manner, creating a distinct fit between context, structure, and performance (Gerdin and Greve 2004). For instance, such episodic change is illustrated by Guenther et al. (2014), as they studied the concept of 'cost stickiness'. Applying the same insight in this context means that there is not necessarily a linear cost development for making 
switches or rapid changes in the working capital level. For instance, Huson and Nanda (1995) argue that the inventory variable has limitations in production capacity or inventory storage, which makes the shift from one configuration to another costly. As a consequence, there are resource constraints on making incremental changes in the inventory level. This means there exist distinct configurations of inventory set-up, and movement between one configuration and another represents a movement to a different type and not an incremental adjustment of inventory set-up.

There have been only some limited attempts at empirical WCM research to adopt configurational theorizing when studying WCM. One of the earliest attempts was by Weinraub and Visscher (1998) who studied the correlation between OWC and FWC. However, the results only showed associative relationships at the aggregate level. Furthermore, firm performance was not considered in this study. While Howorth and Westhead (2003) linked packages of WCM to financial performance, they studied only the OWC dimension. For instance, one of the four distinct packages in their study was solely related to inventory management. The same goes for Galeazzo and Furlan (2018) and Karatzas et al. (2016), as they only link packages consisting of production and inventory techniques to financial performance. Talonpoika et al. (2016) shifted focus from OWC to FWC. The results showed 11 different packages for achieving effective FWC. However, as the FWC was the outcome variable, it is difficult to say whether this also contributes to financial performance. Furthermore, they did not study how each component in OWC and FWC may be combined into effective WCMPs.

However, most of the empirical WCM literature is based on Cartesian theorizing, typically trying to establish direct and indirect effects between independent and dependent variables (Ragin 2008). Ragin (2000) termed this type of research as based on 'net-effects thinking'. In this case, WCM was seen as consisting of variables that exist independently of each other, having a unique net effect on financial performance. The empirical WCM literature suggests a mostly direct type of net effects between variables from WCM and financial performance (García-Teruel and Martínez-Solano 2007; Baños-Caballero et al. 2010, 2012, 2014, 2016, 2019; Martínez-Sola et al. 2014; Gama and Pais 2015; Lyngstadaas and Berg 2016; Zeidan and Shapir 2017). The main conclusion is that a firm should keep WCM level low to positively affect financial performance measures such as ROA.

Another related research stream has focused on determining the optimal level of WCM (García-Teruel and Martínez-Solano 2010; Venkiteshwaran 2011; Baños-Caballero et al. 2014; Kim and Bettis 2014; Mun and Jang 2015; Nason and Patel 2016). The main idea is that moving too far away from the optimal level of WCM would have a detrimental effect on financial performance. These studies commonly find a negative effect of deviating too much from the optimal level of WCM on financial performance. However, these scholars assumed that there is only one optimal working capital level existing at a time (given the constraints that the same contingencies impose), and incremental changes can be made for closing the gap between actual and optimal levels of working capital. 


\subsection{Working capital management as complementary or substitutive systems}

WCMPs, in this paper, are understood as combinations of OWCs and/or FWCs. If there exists systematic interdependency within or between OWC and FWC, then they are viewed as systems. A systematic interdependency is believed to exist if there is a statistically significant interaction term between two or more components in a given WCMP.

OWC is commonly interpreted and operationalized in the same manner as the cash conversion cycle (Gitman 1974). This means that inventory, accounts receivable, and accounts payable are the three main components constituting OWC. OWC is the working capital requirement for conducting daily business operations. The requirement is determined by the time gap between the outflow and inflow of cash from these daily business operations (Gitman 1974). However, there are also other components related to OWC that may be relevant (such as prepaid expenses). As such, other current assets will also be added as a component of OWC in this study.

FWC reflects how working capital is financed. While accounts payable are part of OWC, they also represent a source for financing working capital. As such, accounts payable, cash holding (cash plus short-term investments), and other short-term liabilities (such as bank-based loans) are often part of the financing debate regarding complements or substitutes among working capital components. The debate about FWC being a complement or a substitute also represents two different main strands in current corporate financial theory. Meltzer (1960) is often associated with the substitutive perspective, while Biais and Gollier (1997) and Jain (2001) propose a complementary perspective. The substitution perspective argues that supplier trade credit is an expensive financing form (a typical example is the supplier's offer of a $2 \%$ discount if paying before 10 days, otherwise pay per 30 days without discount) (Fabbri and Menichini 2010). The main argument is that other sources of financing are cheaper compared to trade credit (Gatev and Strahan 2006).

However, Fabbri and Menichini (2010) contend that there is a lack of empirical support for that above argument, which means the two views are more of a theoretical than practical relevance. Wilner (2000) shows that most firms use supplier trade credit despite the associated costs. Probably, trade credit may serve as a signalling dynamic between buyer and supplier and for the financial institutions. The supplier may interpret early payment as a sign of a customer's creditworthiness and be willing to extend further supplier trade credit (Wilner 2000). Banks may interpret the extension of supplier trade credit as a signal of creditworthiness of their client firm and be willing to extend to the firm more short-term credit (Biais and Gollier 1997; Cuñat and Garcia-Appendini 2012). This is also supported by Aktas et al. (2015) and Kling et al. (2014) who demonstrated the signalling effect of the tenor of supplier trade credit on external investors.

Cash holding can also be used in a complementary or substitutive way. Bates et al. (2009) list several potential motivations for keeping cash. Precaution in one of the motives. Holding cash gives financial flexibility and slack (Bates et al. 2009; Han and Qiu 2007; Kim and Bettis 2014). Cash holding can complement the other components of working capital by providing a buffer against shocks in demand and supply. 
The substitutive perspective of cash holding rather suggests it should be kept at a minimum. This is based on three main arguments (Demiroglu and James 2011). First, from an agency perspective, it overcomes the potential managerial problem of not investing cash in the most value-enhancing ways (Jensen 1986; Bertrand and Mullainathan 2003; Richardson 2006). Second, cash holdings typically earn less than the cost of short-term debt used to fund it. Therefore, accumulation of cash is unproductive (Demiroglu and James 2011; Picconi and Oler 2014; Nason and Patel 2016). Third, interest payments on credit lines are tax-deductible, while interest earned on cash holding is subject to tax (Demiroglu and James 2011). This leads to the reasoning that it is better to borrow cash as and when needed from credit providers rather than accumulate it in the first place (Gatev and Strahan 2006).

\section{Research framework}

\subsection{Data collection}

This study uses the CRSP/Compustat database for obtaining financial statements for listed North American manufacturing firms registered at the New York Stock Exchange (NYSE). The sample is collected for the fiscal period 2012-2019. The fiscal period of 2011 is included for variables requiring estimation of annual change. Standard Industrial Classification (SIC) codes are used for identifying manufacturing firms. Those firms registered in the SIC code span 2000-3999 are here defined as manufacturing firms. All financial statements are collected at the consolidated level. To capture firms with regular business activity over time, a minimum of 4 years' financial statements are required.

Table 1 provides descriptive statistics about the firms included in the study. Frequency measures the number of unique firms within a given manufacturing industry. The Compustat database consists of 1.785 unique firms in the sample period (2012-2019) that are registered at NYSE. Filtering firms with a minimum of 4 years' business history creates a sample of 589 unique firms, totalling up to 4255 firm-year observations. Typically, listed firms are large and may be different as compared to smaller firms (differences may stem from various factors, such as risk orientation, competitive advantage, financial flexibility, and access to capital). For instance, one qualifying criterion to be listed at NYSE is to ensure that the market value of public shares of the firm is at least $\$ 40$ million. Therefore, the data sample may not be representative of all manufacturing firms in the U.S.

\subsection{Selection of variables}

Table 2 provides a summary of the relevant variables included in the study, as well as their corresponding variable name in the CRSP/Compustat database. The following section will describe why these variables are included.

All variables of interest have been winsorized at the $1 \%$ level to mitigate the effect of abnormal values, i.e. outliers. The winsorization process was filtered by year. The 
Table 1 Manufacturing industries included in the study $(\mathrm{N}=589)$

\begin{tabular}{llr}
\hline Manufacturing sector & Frequency & $\%$ \\
\hline Total unique firms in the sample period & 1.785 & \\
Firms $\geq 4$ years of business history & 589 & 100 \\
Type of industry & & \\
Food, beverage, and tobacco & 50 & 8 \\
Textile and apparel & 18 & 3 \\
Lumber and wood products & 21 & 4 \\
Paper, printing, and allied products & 35 & 6 \\
Chemicals and allied products & 97 & 16 \\
Petroleum refining and related industries & 30 & 5 \\
Rubber, leather, mineral, and miscellaneous plastic products & 32 & 5 \\
Primary metal and fabricated metal products & 54 & 14 \\
Industrial and commercial machinery and equipment & 80 & 11 \\
Electrical equipment and variables & 65 & 9 \\
Measuring, analysing, and controlling instruments & 52 & 9 \\
Transportation equipment & 55 & 100 \\
Total & 589 & \\
\hline
\end{tabular}

final sample consists of an unbalanced panel of 589 firms (4255 firm observations). The median values for financial performance and components in WCM for the sample period were used to conduct fsQCA (see Table 3). Control variables were added when running panel data regressions.

The accounting return dimension of financial performance is examined by using both profitability and liquidity measures (Hamann et al. 2013). ROA is used as a measure of profitability and is often adopted in empirical WCM research as the outcome variable (see for instance García-Teruel and Martínez-Solano 2007; BañosCaballero et al. 2010; Gill et al. 2010; Enqvist et al. 2014; Gama and Pais 2015; Lyngstadaas and Berg 2016). ROA is measured as EBIT/total assets. A liquidity (CFLOW) measure will be used for adding robustness to the findings. CFLOW is measured as net cash flow from operating activities/total assets.

WCM is here defined as OWC +FWC. OWC consists of four variables: inventory, accounts receivable, accounts payable, and other current assets. Inventory, accounts receivable, and accounts payable are three variables from the cash conversion cycle. However, WCM in its broadest sense is the difference between current assets and current liabilities. As such, this study will also include other current assets (for instance, prepaid expenses) to the measurement of OWC. All variables in OWC are scaled by net sales (Mun and Jang 2015). Compustat defines net sales as gross sales minus cash discounts, trade discounts, and returned sales and allowances. This measure excludes inter-company sales, interest and rental income, and non-operating income. Inventory is measured as total inventory/net sales (INV). Accounts receivable is measured as trade receivables/net sales (ACR). Accounts payable is measured as trade payables/net sales (ACP). Other current assets are measured as total current assets minus total inventory, trade receivables, and cash 
Table 2 Overview of variables

\begin{tabular}{|c|c|c|c|}
\hline Variable & Description & Measurement & Variable name Compustat \\
\hline \multicolumn{4}{|c|}{ Firm performance } \\
\hline ROA & Return on assets & $\begin{array}{l}\text { Earnings before interest and } \\
\operatorname{tax} \\
\text { Total assets }\end{array}$ & $\begin{array}{l}\text { EBIT } \\
\text { TA }\end{array}$ \\
\hline CFLOW & Liquidity & $\begin{array}{l}\text { Net cash flow from operating } \\
\text { activities } \\
\text { Total assets }\end{array}$ & $\begin{array}{l}\text { OANCF } \\
\text { TA }\end{array}$ \\
\hline \multicolumn{4}{|l|}{$O W C$} \\
\hline INV & Inventory & $\begin{array}{l}\text { Inventory total } \\
\text { Net sales }\end{array}$ & $\begin{array}{l}\text { INVT } \\
\text { SALE }\end{array}$ \\
\hline ACR & $\begin{array}{l}\text { Accounts receivable } \\
\text { (trade) }\end{array}$ & $\begin{array}{l}\text { Trade receivables } \\
\text { Net sales }\end{array}$ & $\begin{array}{l}\text { RECTR } \\
\text { SALE }\end{array}$ \\
\hline $\mathrm{ACP}$ & $\begin{array}{l}\text { Accounts payable } \\
\text { (trade) }\end{array}$ & $\begin{array}{l}\text { Trade payables } \\
\text { Net sales }\end{array}$ & $\begin{array}{l}\text { AP } \\
\text { SALE }\end{array}$ \\
\hline CA_OTHER & Other current assets & $\begin{array}{l}\text { Current assets total-inven- } \\
\text { tory-receivable trade-cash } \\
\text { holding } \\
\text { Net sales }\end{array}$ & $\begin{array}{l}\text { ACT-INVT-RECTR-CHE } \\
\text { SALE }\end{array}$ \\
\hline \multicolumn{4}{|l|}{$F W C$} \\
\hline $\mathrm{CASH}$ & Cash holding & $\begin{array}{l}\text { Cash + short-term invest- } \\
\text { ments } \\
\text { Net sales }\end{array}$ & $\begin{array}{l}\text { CHE } \\
\text { SALE }\end{array}$ \\
\hline CURR_LIAB & $\begin{array}{r}\text { Current liabilities } \\
\text { (excl. payables) }\end{array}$ & $\begin{array}{l}\text { Current liabilities-accounts } \\
\text { payable trade } \\
\text { Net sales }\end{array}$ & $\begin{array}{l}\text { LCT-ACP } \\
\text { SALE }\end{array}$ \\
\hline \multicolumn{4}{|c|}{ Firm characteristics } \\
\hline LEV & Leverage & $\begin{array}{l}\text { Total liabilities } \\
\text { Total assets }\end{array}$ & $\begin{array}{l}\text { LT } \\
\text { TA }\end{array}$ \\
\hline LIAB_RATIO & $\begin{array}{l}\text { Current liabilities } \\
\text { ratio }\end{array}$ & $\begin{array}{l}\text { Current liabilities total } \\
\text { Total liabilities }\end{array}$ & $\begin{array}{l}\text { LCT } \\
\text { LT }\end{array}$ \\
\hline CA_RATIO & Current assets ratio & $\begin{array}{l}\text { Current assets total } \\
\text { Total assets }\end{array}$ & $\begin{array}{l}\mathrm{ACT} \\
\mathrm{TA}\end{array}$ \\
\hline GROW & Firm growth & $\begin{array}{l}\text { Employee }_{t}-\text { employee }_{t-1} \\
\text { Employee }_{t-1}\end{array}$ & $\begin{array}{l}\mathrm{EMP}_{\mathrm{t}}-\mathrm{EMP}_{\mathrm{t}-1} \\
\mathrm{EMP}_{\mathrm{t}-1}\end{array}$ \\
\hline FINCON & Financial constraint & $\begin{array}{l}\text { Dividend } \\
\text { Net sales }\end{array}$ & $\begin{array}{l}\text { DVC } \\
\text { SALE }\end{array}$ \\
\hline FINDIST & Financial distress & $\begin{array}{l}\text { Altman } Z=1.2 X_{1}+1.4 X_{2}+3 \\
.3 X_{3}+0.6 X_{4}+1.0 X_{5}\end{array}$ & \\
\hline
\end{tabular}

$\mathrm{X}_{1}=$ working capital/total assets, where working capital is current assets minus current liabilities (WCAP/TA); $\mathrm{X}_{2}=$ retained earnings/total assets (RE/TA); $\mathrm{X}_{3}=$ EBIT/total assets (EBIT/TA); $\mathrm{X}_{4}=\mathrm{mar}$ ket value equity/book value of total liabilities (MKVALT/LT); $\mathrm{X}_{5}=$ net sales/total assets (SALE/TA); and Altman $\mathrm{Z}=$ overall index score. Compustat variable name in parenthesis

holding/net sales (CA_OTHER). FWC consists of two variables: cash holding and current liabilities (excluding accounts payable). Cash holding is measured as cash plus short-term investments/net sales (CASH). Current liabilities are measured as total current liabilities minus trade payables/net sales (CURR_LIAB). 
Table 3 Calibration procedure and thresholds for membership scores of conditions and outcome $(\mathrm{N}=589)$

\begin{tabular}{lllll}
\hline Conditions and outcome & Fuzzy set measure & \multicolumn{2}{l}{ Fuzzy set calibrations } & \\
\cline { 3 - 5 } & & Fully in & Crossover & Fully out \\
& & 90 th percentile & 50th percentile & 10th percentile \\
\hline Outcome & & & \\
ROA & Return on assets & 0.168 & 0.089 & 0.032 \\
Conditions & & & & \\
INV & Inventory & 0.235 & 0.128 & 0.063 \\
ACR & Accounts receivable & 0.218 & 0.129 & 0.052 \\
ACP & Accounts payable & 0.142 & 0.083 & 0.041 \\
CASH & Cash holding & 0.354 & 0.097 & 0.023 \\
CA_OTHER & Other current assets & 0.086 & 0.036 & 0.016 \\
CURR_LIAB & Current liabilities & 0.312 & 0.129 & 0.058 \\
& $\quad$ (excl. payables) & & & \\
\hline
\end{tabular}

The panel data regression will be run with several control variables. Control variables are added to diminish the risk of endogeneity due to model misspecification (i.e. omitted variable problem) (Chenhall and Moers 2007; Van Lent 2007; Larcker and Rusticus 2010; Zaefarian et al. 2017). Endogeneity creates concern, as it can lead to biased and inaccurate results, potentially leading to erroneous conclusions about systematic interdependencies. What happens is that the residual error term correlates with the independent variables, making the error term not random. The effect of the independent variable on the dependent variable becomes biased by other unobservable effects that correlate with the independent variable and that also explains the dependent variable (Chenhall and Moers 2007; Van Lent 2007; Larcker and Rusticus 2010; Zaefarian et al. 2017). Three types of control variables are added: debt structure, firm growth, and financial situation.

The debt structure is related to how working capital is financed. Current liabilities will most commonly be used for financing working capital because both are of a short-term nature. However, as leverage increases, the risk of default may increase as well. The cost advantages of financing working capital through short-term debt may quickly turn into cost disadvantages (Baños-Caballero et al. 2016). The controlling variables for debt structure are leverage, current assets ratio, and current liabilities ratio. Leverage is measured as total liabilities/total assets (LEV) (Martínez-Sola et al. 2013), current asset ratio as current assets/total assets (CA_RATIO) (Gama and Pais 2015; Lyngstadaas and Berg 2016), and current liabilities ratio as current liabilities/total liabilities (LIAB_RATIO) (Gama and Pais 2015; Lyngstadaas and Berg 2016).

Firm growth may indicate future sales and production and, potentially, affect the firm's working capital requirements. Firm growth is measured as the annual change in the number of employees (GROW). 
The financial situation affects a firm's financial flexibility. Financial flexibility is understood here as the capability to capitalize on financial resources by taking preventive and exploitive actions (Byoun 2011). There are two different ways of understanding the constraints on financial flexibility: financial constraint and probability of default (financial distress). Financially constrained firms have less access to external and internal capital. The consequence may be forgoing positive net present value projects that would potentially negatively affect future production and sales. Following Almeida et al. (2004) and Faulkender and Wang (2006), the payout ratio is used as a proxy for financial constraint. While it may be argued that even profitable firms do not necessarily pay out dividends, Fazzari et al. (1988) show that financially constrained firms have a lower payout ratio compared to firms that are not financially constrained. Financially constrained firms also have higher investment sensitivity and fewer internal sources of funding (Arslan et al. 2006). This may also impede the firm in accessing the necessary sources for financing working capital. The payout ratio is measured as total dividends/net sales (FINCON) (Faulkender and Wang 2006).

The probability of default indicates the firm's degree of financial distress and the probability that the firm may become insolvent. Since this study looks at the manufacturing sector, the Altman Z-score will be used to measure the level of financial distress (FINDIST). The use of the Altman Z-score is appropriate because it was originally developed for application in the manufacturing sector (Altman 1968, 2013). The Altman Z-score is a function of five variables (see Table 2). A higher Z-score indicates less probability of default.

\subsection{Methods}

Several researchers argue that fsQCA and statistical methods may be used in a complementary manner (Rihoux 2006; Ragin 2008; Schneider and Wagemann 2010). While some studies use fsQCA for analysis of both packages and systems (see for instance Misangyi and Acharya 2014), Ragin (2008, p. 190) argues that fsQCA is not an inferential method per se. Even though probabilistic criteria may be incorporated into fsQCA, the scientific assumptions are based on set theory (Ragin 2008). This means that fsQCA can inform the researcher about the necessity and sufficiency of how conditions are related to an outcome of interest, but it is not possible to draw statistical inferences (Rihoux 2006; Ragin 2008; Schneider and Wagemann 2010). This limits the possibility that fsQCA could serve to draw causal inferences about systematic interdependencies between conditions. Moreover, the number of conditions that may be analysed simultaneously with fsQCA is limited. The number of logical combinations between conditions increases exponentially at the rate of $2^{\mathrm{k}}$ ( $\mathrm{k}$ is the number of conditions), which swiftly raises the complexity of the analysis to an overwhelming degree (Ragin 2008). As a result, control variables commonly used in regression analysis are left out in fsQCA. Rihoux (2006, pp. 695-687) and Greckhamer et al. (2013) argue that set theory was initially developed for cross-section small N-samples, focusing on thick descriptions of the cases. The move towards using large $\mathrm{N}$-samples and capturing time dynamics have enhanced the importance 
of complementing with other statistical methods in fsQCA-based research (Rihoux 2006; Greckhamer et al. 2013; Meuer and Rupietta 2017). Vis (2012) argues that although fsQCA and statistical methods contain different epistemological assumptions, ${ }^{5}$ they should be viewed as complementary rather than mutually exclusive analytical methods.

\subsubsection{Fuzzy set qualitative comparative analysis}

The first research question is analysed using fsQCA (Ragin 2000, 2008, 2014). fsQCA is a set theory-based methodology that resonates with configurational theorising. The main advantage of fsQCA is the assumption of interrelationship and interdependency. Examining such assumptions has traditionally been an analytical challenge in management accounting and control research (Bedford and Malmi 2015). The main advantage is that fsQCA studies a combination of multiple conditions, as opposed to covariance-based net-effect approaches that consider only a selection of a few key variables at a time.

Conducting fsQCA involves several steps. The first step is to identify relevant conditions and outcomes. In this context, the dependent variable (here, high levels of ROA) will be the outcome of interest. The independent variables (here, components in WCM) act as conditions. The conditions are viewed as 'causal recipes' for obtaining the outcome of interest (Ragin 2008). The next step is to calibrate the variables. The variables are converted into membership scores, being a form of standardised calibration process (Fiss 2011). Three anchor points must be defined for assigning membership scores to the conditions and outcome. These are 0 (fully out/ absent), 1 (fully in/present), and 0.5 (crossover point). This study follows the same calibration procedure as Talonpoika et al. (2016). The 10th percentile in the sample is used to indicate a membership score of 0 (fully out), the 90th percentile as 1 (fully in), and the median as the crossover point (Talonpoika et al. 2016). The calibration procedure and membership thresholds are shown in Table 3. The question is how to handle cases of maximum ambiguity (i.e. membership score of 0.5 ). The point of ambiguity is whether these cases are more in than out or vice versa. There are two different ways of mitigating this issue: (1) drop the cases with maximum ambiguity (i.e., exclude them from fsQCA) or (2) add or subtract a constant that makes the membership score not equal to 0.5 (i.e., make them includable in fsQCA). The approach selected for this study was not to add a constant to those membership scores lying exactly at the crossover point, which was a recommendation by Wagemann et al. (2016). The reason is that the results may be affected by how constants are included in fsQCA. Adding or subtracting a constant makes cases with the maximum ambiguity shift from being 'more in than out' to 'more out than in'. This

\footnotetext{
5 Three key assumptions differ from standard econometric theory: causal asymmetry, equifinality, and conjunctural causation (Ragin 2000, 2008, 2014). Causal asymmetry means, for instance, that presence of a condition leads to the presence of the outcome, does not necessarily mean the same as stating that absence of that condition will lead to the absence of the outcome. Equifinality exists when more than one or combination of conditions can lead to the same outcome. Conjunctural causation refers to how conditions lead to the outcome first when they are combined into distinct configurations (Ragin 2000, 2008, 2014). Standard econometric theory typically assumes symmetric correlation, unifinality, and net effects.
} 
may alter the solutions. Further, there are no logical reasons for deciding whether a constant should be added or subtracted.

The third step is to create truth tables. The truth table shows all 64 possible configuration solutions from the six conditions $\left(2^{6}\right.$ solutions). One row in the truth table equals one unique configuration of conditions. One row may contain less or more than one empirical case exhibiting this specific configuration. Conditions can be shown to be redundant, present, or absent with regard to the presence of the outcome of interest (Ragin 2008). Two types of fit indices are commonly used for evaluating fsQCA solutions: consistency (sufficiency) and coverage (necessity). Consistency is a measure of the degree to which a condition is a subset of an outcome (Ragin 2000, $2008,2014)$. This is somewhat similar to the significance testing in statistical tests. A higher score of up to 1 indicates that configurations show high consistency in achieving the same outcome. A lower score down to 0 indicates that configurations do not show the same outcome. ${ }^{6}$ While Ragin (2008) suggests a consistency threshold of at least 0.75 for small case studies, he also remarks that a more conservative threshold, such as at least 0.85 , should be set for a larger data sample size. That is the threshold employed in this study. Necessity is measured through coverage. Coverage measures the degree to which an outcome is a subset of conditions. In other words, coverage shows the extent to which a causal combination can 'account for' the instances in the outcome. This is somewhat similar to the R-squared reporting in linear regression analysis (Ragin 2008). Following earlier empirical practice, the threshold is set to a minimum of three cases per configuration (Fiss 2011; Greckhamer et al. 2013; Ordanini et al. 2014; Talonpoika et al. 2016). This may reduce potential measurement errors, but at the same time, it is acknowledged that relatively few cases may exhibit interesting configurations.

A Boolean minimization technique seeks to find the conditions and configurations that produce the outcome and simultaneously reduces solution complexity. After minimization, the configurations may then be linked back to the number of cases showing that specific configuration (Ragin and Rihoux 2009). Each configuration in the solution represents an effective WCMP for achieving financial performance. In other words, the configurational perspective suggests that each package represents a state of fit between the structure of WCM and financial performance.

Ragin (2008) argues that almost every empirical phenomenon will have some tendency in terms of how conditions are combined. In other words, diversity is limited when it comes to variation in configurations. This is often shown by how certain configurations do not exist empirically (although they are theoretically possible). These configurations are called 'logical remainders'. Consequently, fsQCA produces three solutions: complex, parsimonious, and intermediate. The distinctions between these three solutions are based on how they deal with counterfactuals as a remedy for managing limited diversity. Easy counterfactuals add the presence of redundant conditions to solutions, while difficult counterfactuals add an absence of condition to the solutions (Fiss 2011). Easy counterfactuals are based on the assumption that the absence of a condition will produce the outcome, while difficult counterfactuals

\footnotetext{
${ }^{6}$ See "Appendix" for further description of the consistency, coverage, and minimization procedure in fsQCA.
} 
are based on the assumption that presence (and not absence) of a condition should produce the outcome. In other words, they use the opposite assumptions for making counterfactual analysis (Fiss 2011). Complex solutions do not add counterfactuals, in other words, there are no simplified assumptions of the solutions. A parsimonious solution adds both easy and difficult counterfactuals, while an intermediate solution adds only easy counterfactuals (Fiss 2011).

An intermediate solution is used in this study, as it requires less counterfactual assumptions while trying to achieve solutions that simpler solutions than the most complex solution (Baumgartner 2015). Baumgartner (2015) argues that it is often theoretically difficult or impossible to fully justify the addition of both the easy and difficult counterfactuals. This makes the intermediate solution a pragmatic approach where simpler solutions are preferred if they do not entail making too many assumptions (Baumgartner 2015). That being said, there is only one logical solution left (solution in which INV, ACP, CASH, and CURR_LIAB are absent, and ACR and CA_OTHER are present). This could explain why there are very few differences regardless of the selected solution, and all conditions are either identified as core or redundant (not peripheral) (Fiss 2011). To conduct fsQCA, fsQCA software 3.1 developed by Ragin (2008) was used.

\subsubsection{Panel data regression}

The second research question will be answered by using panel data regression. Panel data regression is selected as fsQCA can only show empirical concordance and cannot be used for drawing statistical inferences (Fiss et al. 2013b). As argued by Grofman and Schneider (2009), finding conditions to be sufficient for achieving the outcome is not the same as establishing causal inference.

While panel data regression can be used to detect asymmetric interaction effects (see for instance Mun and Jang 2015), the interaction analysis is often limited to two- or maximum three-way interactions. Using fsQCA as a point of departure makes it possible to add even more possible interactions that enable the examination of highly complex relationships. The panel data regression analysis may then be used for verifying the fsQCA solutions (Fiss et al. 2013b).

Two different types of panel data regression will be run. Fixed-effect panel data regression (FE-regression) captures individual heterogeneity that may change over time and affect financial performance. The individual heterogeneity is contained within firms and not between firms. This may limit the omitted variable bias (Allison 2009). The fixed-effect panel data regression controls all time-invariant differences among the firms (such as a firm being a part of the manufacturing sector), so the model does not become biased due to omitted time-invariant characteristics (Allison 2009).

The fixed-effect panel data regression is shown in Eq. 1: 


$$
\begin{aligned}
\left(\mathrm{ROA}_{i}, t\right)= & \beta 0+\beta_{1}(\mathrm{INV}) i, t+\beta_{2}(\mathrm{ACR}) i, t+\beta_{3}(\mathrm{ACP}) i, t+\beta_{4}(\mathrm{CASH}) i, t \\
& +\beta_{5}\left(\mathrm{CA} \_\mathrm{OTHER}\right) i, t+\beta_{6}\left(\mathrm{CURR} \_\mathrm{LIAB}\right) i, t+\beta_{7}(\mathrm{LEV}) i, t \\
& +\beta_{8}\left(\mathrm{CA} \_\mathrm{RATIO}\right) i, t+\beta_{9}\left(\mathrm{LIAB} \_\mathrm{RATIO}\right) i, t+\beta_{10}(\mathrm{GROW}) i, t \\
& +\beta_{11}(\mathrm{FINCON}) i, t+\beta_{12}(\mathrm{FINDIST}) i, t+\lambda \mathrm{t}+v i+\varepsilon i, t
\end{aligned}
$$

The variables and their measurement have been introduced in the Variables section. Each variable is observed at each firm $(i)$ during a given time period $(t) . \lambda \mathrm{t}$ controls for the time effect and is a year dummy variable that changes in time but is equal for all firms in each of the fiscal periods under consideration. Unobservable heterogeneity $v_{i}$ is for each firm, and $\varepsilon_{i, t}$ captures the residual error term (unobservable factors that vary over time and affect ROA). All estimations are run with robust standard errors (Huber 1967; White 1980).

The challenge of FE-regression is the relatively few time periods $(\mathrm{T})$ but quite a large $\mathrm{N}$ sample. This results in an incidental parameter problem known as the 'Nickell bias' (Nickell 1981). As such, a second estimation procedure is conducted to add robustness to the results. This is a random effect maximum likelihood (RML) estimation procedure. RML is a likelihood-based estimation procedure that may mitigate the incidental parameter problem (Alvarez and Arellano 2003; Bun et al. 2017). Monte Carlo simulations indicate that RML can be an equal alternative to other estimation procedures for handling the incidental parameter problems, such as the generalized method of moments (GMM) (Bun et al. 2017). While GMM is a more common estimation procedure in empirical WCM research (García-Teruel and Martínez-Solano 2010; Baños-Caballero et al. 2016; Altaf and Farooq 2019), the benefit of RML is that it uses the entire distribution and not only specified moments as done in GMM. ${ }^{7}$ To obtain robust standard errors, a bootstrap procedure with 500 replications was run. Stata 16.0 was used for estimations.

\section{Results}

\subsection{Descriptive statistics and bivariate correlations}

Table 4 contains the correlation matrix of the included variables. There are two correlations between 0.5 and 0.6. These are between ROA and FINDIST (0.51) and CA_RATIO and LIAB_RATIO (0.60). However, the maximum variance inflation factor (VIF) is 3.96. This is well below the suggested threshold of a maximum of 10 (Hair et al. 2013). This indicates that multicollinearity is not a problem in the study.

\footnotetext{
7 An anonymous reviewer made this relevant and important remark when selecting the estimation procedure.
} 


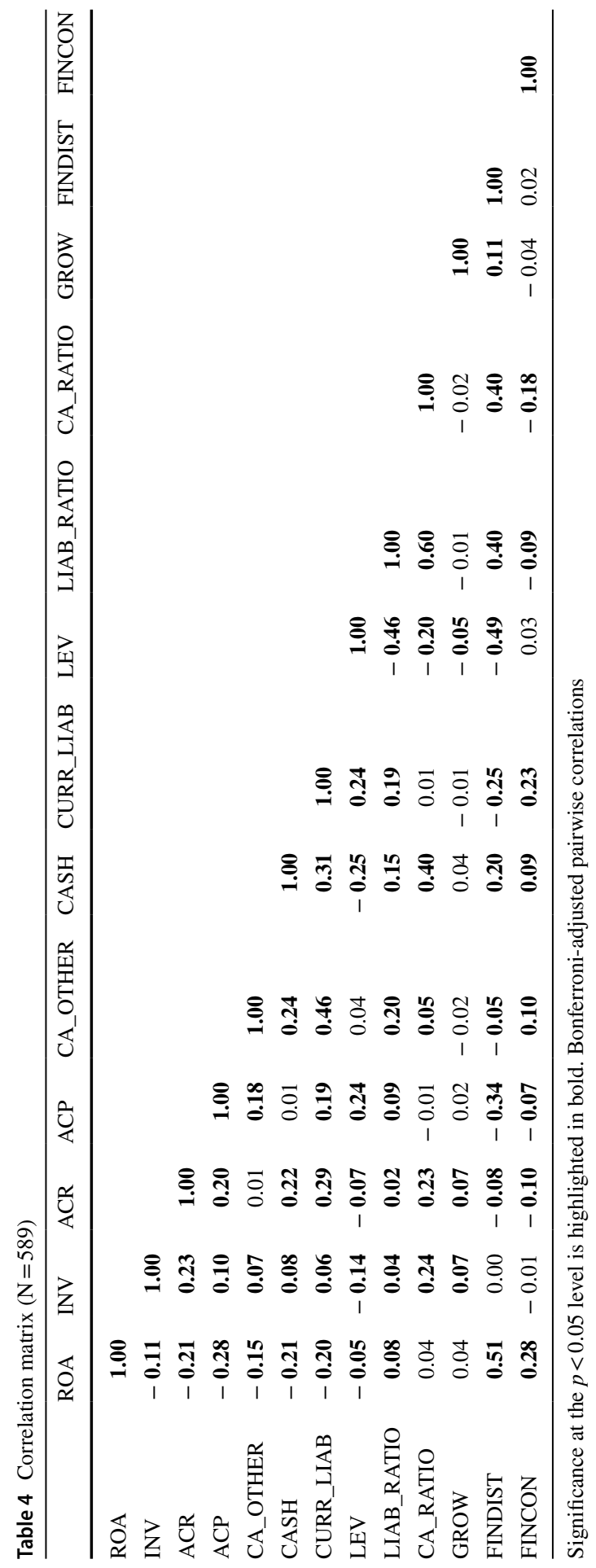


Table 5 Descriptive statistics of variables $(\mathrm{N}=589)$

\begin{tabular}{lllllllr}
\hline Variable & Mean & Median & SD & 25th perc. & 75th perc. & Min & Max \\
\hline ROA & 0.09 & 0.09 & 0.08 & 0.06 & 0.13 & -0.23 & 0.38 \\
INV & 0.14 & 0.13 & 0.08 & 0.09 & 0.18 & 0.01 & 0.44 \\
Raw & 0.32 & 0.32 & 0.20 & 0.17 & 0.45 & 0.00 & 0.83 \\
Work & 0.17 & 0.11 & 0.19 & 0.01 & 0.24 & 0.00 & 0.84 \\
Finished & 0.46 & 0.49 & 0.25 & 0.28 & 0.64 & 0.00 & 0.99 \\
Other & 0.05 & 0.00 & 0.19 & 0.00 & 0.00 & 0.00 & 0.99 \\
ACR & 0.14 & 0.13 & 0.07 & 0.09 & 0.18 & 0.00 & 0.56 \\
ACP & 0.09 & 0.08 & 0.05 & 0.06 & 0.11 & 0.02 & 0.30 \\
CASH & 0.16 & 0.10 & 0.19 & 0.04 & 0.19 & 0.01 & 1.27 \\
CA_OTHER & 0.05 & 0.04 & 0.05 & 0.02 & 0.6 & 0.00 & 0.35 \\
CURR_LIAB & 0.16 & 0.13 & 0.12 & 0.08 & 0.21 & 0.00 & 0.73 \\
LEV & 0.59 & 0.58 & 0.22 & 0.45 & 0.70 & 0.11 & 1.33 \\
LIAB_RATIO & 0.40 & 0.36 & 0.20 & 0.26 & 0.51 & 0.00 & 0.97 \\
CA_RATIO & 0.41 & 0.39 & 0.17 & 0.29 & 0.52 & 0.00 & 0.91 \\
GROW & 0.04 & 0.01 & 0.17 & -0.03 & 0.07 & -0.36 & 0.99 \\
FINDIST & 3.39 & 2.80 & 2.78 & 1.77 & 4.11 & -1.56 & 18.11 \\
FINCON & 0.03 & 0.01 & 0.04 & 0.00 & 0.03 & 0.00 & 0.27 \\
\hline & & & & & & 0.00 \\
\hline
\end{tabular}

Table 5 presents the descriptive statistics of the variables included in the study. Inventory is further decomposed into its main four sub-components (raw materials, work in process, finished goods, and other inventory ${ }^{8}$ ). The inventory sub-components are reported according to how much of the total inventory they constitute, while the inventory variable is scaled by net sales.

\subsection{Working capital management packages}

A test for causal necessity was conducted before the fsQCA to ascertain the conditions that are necessary to produce the outcome and the sufficient (combinations of) conditions are those that will produce the outcome. If there is a necessary condition, it suggests that the outcome is a subset of the condition and the condition is not a subset of the outcome (Ragin 2008). This study uses an approach suggested by Dul (2016) for ascertaining if a single condition is necessary for producing the outcome of interest. This involves using a necessity consistency threshold of 0.9 (Dul 2016, p. 1519). The test included both presence and absence of conditions because it is not known ex-ante what produces the outcome. The threshold for the test for single necessary conditions ranged between 0.56 and 0.70 , which is far below the suggested

\footnotetext{
${ }^{8}$ Other inventory is a group for those inventory items that are difficult to classify into the three other components. This group can include items such as purchased parts for resale and inventory used for the purposes of demonstration. These four components constitute the total inventory in CRSP/Compustat database.
} 
threshold. The conclusion is that there is no sole WCM component (condition) that is necessary for achieving high financial performance (an outcome of interest). ${ }^{9}$

The following results from fsQCA are presented with the use of the common fsQCA notation system (Fiss et al. 2013a; Misangyi and Acharya 2014; Bedford et al. 2016). A solid circle (•) shows the presence of a working capital variable (i.e. condition). A circle with a cross $(\otimes)$ represents the absence of a working capital variable. The presence of a condition means that a firm has a membership score above 0.5 from the calibration procedure. In other words, if a condition/outcome is present, it means that the value of the variable is above the median for the sample group. If a condition/outcome is absent, it means that the value of the variable is below the median for the sample group. Blank spaces mean that conditions are redundant for obtaining the presence of the outcome. ${ }^{10}$ To simplify the remaining presentation, 'low' will be used to denote the absence of a condition, while 'high' will be used to denote the presence of a condition. What is low/high is then relative to the other empirical cases (i.e. firms) in the data sample.

Table 6 shows the results from the fsQCA. ROA is used as the outcome variable, while the variables in OWC and FWC act as conditions. Each configuration lies close to the defined consistency level of 0.85 and far above the minimum consistency threshold of 0.75 (Ragin 2008). This means that the combination of conditions is sufficient for achieving financial performance. It is also important to split coverage into 'raw' and 'unique' coverage when there are many different paths to the same outcome (Ragin 2006b). While there are many sufficient configurations, there are only a few configurations that are empirically important in terms of having high coverage. Table 6 shows that configurations $1-5$ and 11 hold the most empirically relevant solutions and therefore most relevant to focus on in further analysis.

This can be compared somewhat analogously when making an assessment of which variables in a multiple regression explain most of the variation in the outcome variable. In this context, each WCMP accounts for some of the explanations for achieving high financial performance. This is the raw coverage of WCMPs. Since several WCM components are represented in several packages, they overlap in terms of explaining high financial performance. At the same time, since some packages contain WCM components that are unique to that given package, they can also have unique coverage (Ragin 2008; Schneider and Wagemann 2010). This can, to some degree, ${ }^{11}$ be compared when partialling out explained variation in multiple

\footnotetext{
9 The same test for single necessary condition was conducted using the negation of ROA as outcome. The necessary consistency ranged between 0.49 and 0.60 . The conclusion is that no single conditions were found to be necessary for causing the negation of ROA.

${ }^{10}$ It is also possible to distinguish between 'core' and 'peripheral' conditions based on the causal connection between condition and outcome of interest (Fiss 2011). This is done by comparing parsimonious and intermediate solution from the fsQCA, as they are based on distinguishing between easy and difficult counterfactuals (Fiss 2011). However, the causal coreness was not different between parsimonious and intermediate solutions, which means that all conditions are identified as 'core' and none are 'peripheral' conditions in the WCMPs.

11 In fsQCA, the assumption is that conditions cannot be viewed in isolation. This means that their net effect is not estimated in terms of correlation between explanatory variables, but their relative importance in different packages for accounting for explaining the outcome of interest (Ragin 2006b).
} 
Table 6 Configurations of WCMPs for achieving high financial performance $(\mathrm{N}=204)$

\begin{tabular}{|c|c|c|c|c|c|c|c|c|c|c|c|}
\hline WCMP & 1 & 2 & 3 & 4 & 5 & 6 & 7 & 8 & 9 & 10 & 11 \\
\hline \multicolumn{12}{|l|}{$O W C$} \\
\hline INV & $\otimes$ & & $\otimes$ & & - & & - & & & & - \\
\hline ACR & $\bullet$ & $\otimes$ & & & $\otimes$ & & $\otimes$ & & $\otimes$ & $\otimes$ & $\otimes$ \\
\hline $\mathrm{ACP}$ & & & & & $\otimes$ & $\otimes$ & & $\otimes$ & $\otimes$ & $\otimes$ & \\
\hline CA_OTHER & & $\otimes$ & & $\otimes$ & & $\bullet$ & & $\otimes$ & & $\otimes$ & $\otimes$ \\
\hline \multicolumn{12}{|l|}{$F W C$} \\
\hline $\mathrm{CASH}$ & & $\bullet$ & $\bullet$ & $\otimes$ & & $\otimes$ & $\otimes$ & $\bullet$ & $\otimes$ & $\otimes$ & $\bullet$ \\
\hline CURR_LIAB & $\otimes$ & & $\otimes$ & $\otimes$ & $\otimes$ & $\otimes$ & $\otimes$ & $\otimes$ & $\otimes$ & & \\
\hline Consistency & 0.82 & 0.82 & 0.82 & 0.84 & 0.83 & 0.83 & 0.85 & 0.83 & 0.86 & 0.84 & 0.85 \\
\hline Raw coverage & 0.34 & 0.29 & 0.32 & 0.32 & 0.30 & 0.30 & 0.25 & 0.23 & 0.24 & 0.24 & 0.24 \\
\hline Unique coverage & 0.03 & 0.01 & 0.01 & 0.03 & 0.03 & 0.00 & 0.00 & 0.00 & 0.00 & 0.00 & 0.01 \\
\hline Overall solution coverage & 0.64 & & & & & & & & & & \\
\hline Overall solution consistency & 0.76 & & & & & & & & & & \\
\hline
\end{tabular}

A solid circle $(\bullet)$ shows the presence of a working capital variable (i.e. condition). A circle with a cross $(\otimes)$ illustrates the absence of a working capital variable. Blank spaces indicate variable being either present or absent, meaning it is redundant in the package

regression. It is possible to assess a variable's unique contribution in explaining a variation in the outcome variable by creating a fully specified model (all relevant explanatory variables) and then recompute the model while excluding one explanatory variable of interest (Ragin 2006b).

For instance, we can compare configurations 5 and 7 in Table 6. They overlap to a great extent as both configurations contain high levels of inventory, low levels of accounts receivable, and low levels of other current liabilities. The difference is that configuration 5 has low levels of accounts payable, and configuration 7 has low levels of cash holding. The degree of overlap suggests that the coverage in the two configurations is counted twice. This yields a relatively high raw coverage. But both configurations has variables that is unique to the given configuration. Configuration 5 has low levels of accounts payable that is unique compared to configurations 1-4. This results in a unique coverage of 0.03 . Configuration 7 has low levels of cash holding that is different from configuration 5, but low cash holding is also part of both configurations 4 and 6 , so it is not unique in that sense. This result is an unsubstantial coverage of close to zero. Following the same approach as Ho et al. (2016), the interpretation for answering the second research question will not be based on WCMPs 6-10. The reason is that their unique coverage is approximately 0 , meaning they have low empirical importance for explaining high financial performance.

Eleven different WCMPs are found to be sufficient for achieving high financial performance. Out of the 11 WCMPs, six WCMPs have a unique coverage above 0.00 . These are WCMP 1-5 and 11. Based on the unique coverage, WCMP 1, 4, and 5 seem to have the greatest empirical importance. Of all firms in the data sample, 204 firms are associated with high financial performance relative to the other firms. However, as an 
empirical case can be represented in more than one WCMP, there are 129 unique firms in the fsQCA solution.

Table 7 provides descriptive statistics of average ROA, OWC, and FWC in the WCMPs. The total number of firms in the gross sample is in the fsQCA solutions $(N=204)$, while the net sample is the number of unique firms $(N=129)$. Those firms belonging to one of the packages are removed before estimating the total average for the remaining data sample $(N=460)$. The average ROA of those firms in the high-performing group is approximately three percentage points higher than that of the firms in the remaining data sample and seven percentage points above the firms in the lowperforming group (negation of outcome). The high-performing group has a somewhat lower average WCM compared to the remaining data sample. That being said, there are large between-group variations. As can be seen in Table 7, firms belonging to WCMP 2 held on average $39 \%$ of net sales in WC, while firms belonging to WCMP 7 held on average only $9 \%$ of net sales in WC. Such large between-group variations indicate that some have relatively high levels of WC while others have relatively low levels. While WCMP 2 contains approximately 25\% positive FWC, WCMP 7 contains approximately an FWC of negative 16\%. While Mun and Jang (2015) argue that firms with positive $\mathrm{OWC}(\mathrm{OWC} \geq 0)$ and positive $\mathrm{FWC}(\mathrm{FWC} \geq 0)$ may have poor cash-generating capability, the accumulation of cash may be what is required among manufacturing firms. This is based on how cash holding may act as a precaution against future demand shocks and offer strategic flexibility (Bates et al. 2009) to create a positive effect on FWC.

\subsection{Analysis of working capital management packages as systems}

\subsubsection{Proposed systematic interdependencies}

The packages that also contain systematic interdependencies cannot be determined by fsQCA. However, subsequent analysis of the WCMPs can reveal where they most likely exist. The main idea is that if two or more conditions are observed in the same package, they are more likely than not forming an interdependent system (Grabner and Moers 2013). The remaining section will develop proposals and explore which packages may constitute working capital management systems. The proposals are summarised in Table 8.

There are two main challenges in using fsQCA for the analysis of systems. Firstly, fsQCA is an exploratory approach. This implies a lack of theoretical reasoning as to why specific packages form a solution for producing the outcome. Secondly, the complexity quickly becomes overwhelming. Packages containing more than three conditions mean that the solution exists beyond the three-dimensional space. In such cases, the analysis of interaction is likely to prove meaningless or too complex. To overcome the challenge of three- and four-way interactions when running panel data regressions, the respective variables are classified according to being part of OWC or FWC. Then these two variables are caused to interact. OWC and FWC are said to form a system if there is a statistically significant interaction term. 


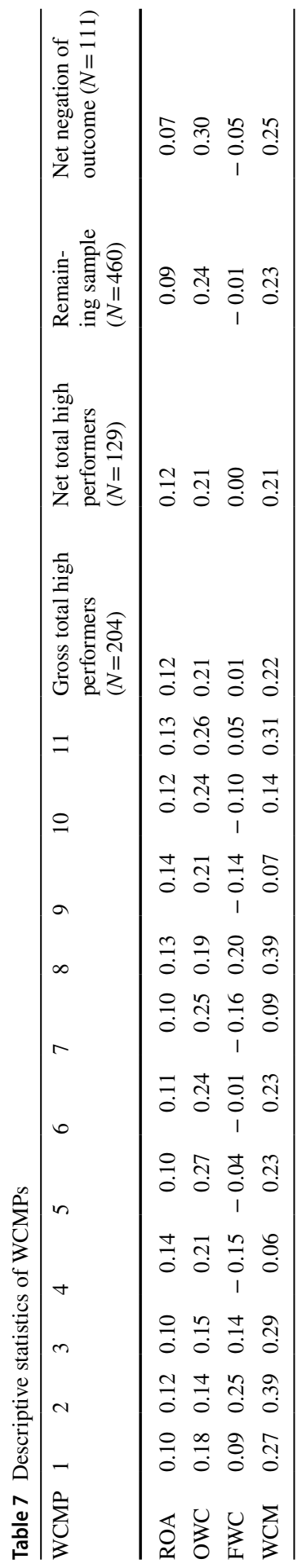


Table 8 Summary of variables included in OWC and FWC for the proposed systematic interdependencies

\begin{tabular}{|c|c|c|c|c|c|c|c|c|}
\hline \multirow{2}{*}{$\begin{array}{l}\text { Systematic } \\
\text { interdepend- } \\
\text { ency }\end{array}$} & \multicolumn{6}{|l|}{ OWC } & \multicolumn{2}{|l|}{ FWC } \\
\hline & $\mathrm{INV}+$ & $\mathrm{ACR}$ & - & $\mathrm{ACP}$ & + & CA_OTHER & $\mathrm{CASH}-$ & CURR_LIAB \\
\hline \multicolumn{9}{|l|}{ Proposal } \\
\hline 1 & $\mathrm{x}$ & $\mathrm{x}$ & & & & & & $\mathrm{x}$ \\
\hline 2 & & $\mathrm{x}$ & & & & $\mathrm{x}$ & $\mathrm{x}$ & \\
\hline 3 & $\mathrm{x}$ & & & & & & $\mathrm{x}$ & $\mathrm{x}$ \\
\hline 4 & & & & & & $\mathrm{x}$ & $\mathrm{x}$ & $\mathrm{x}$ \\
\hline 5 & $\mathrm{x}$ & $\mathrm{x}$ & & $\mathrm{x}$ & & & & $\mathrm{x}$ \\
\hline 6 & $\mathrm{X}$ & $\mathrm{X}$ & & & & $\mathrm{X}$ & $\mathrm{X}$ & \\
\hline
\end{tabular}

$\mathrm{X}$ is the included variable in the interaction term between OWC and FWC, and blank space shows that a variable is not included in the interaction term

Proposal 1 corresponds to WCMP 1 . This package contains the variables INV, ACR, and CURR_LIAB. Two of the variables are part of OWC and one as part of FWC. Keeping a low level of inventory is commonly associated with production philosophies such as lean management (Kanban, just-in-time, standardization, etc.) (Womack and Jones 2003). This package keeps relatively less in current liabilities but, at the same time, increases levels of accounts receivable. A possible reason is that the current liabilities decrease the total assets, while the increased ACR contributes to increased sales. The firms pursuing this tactic may use more liberal trade policies in their accounts receivable management to attract more customers. This leads to the first proposal:

Proposal 1 There exist systematic interdependencies between inventory, accounts receivable, and current liabilities.

Variables INV plus ACR (OWC) interact with CURR_LIAB (FWC).

Proposal 2 corresponds to WCMP 2. This package contains the variables ACR, CA_OTHER, and CASH. This package seems to benefit from decreasing total assets by ACR and CA_OTHER. However, this may be compensated by high levels of cash, which can be due to improved cash flow from the decreased accounts receivable. A possible reason that firms pursue lower accounts receivable can be the desire to make finer discrimination between customers ( $\mathrm{Ng}$ et al. 1999). More aggressive collection or direct payment from customers can decrease the likelihood of customers not paying their dues. Furthermore, keeping other current assets low may increase available cash holding. The increased sales, in addition to keeping total assets low, can explain the higher ROA. The second proposal is then: 
Proposal 2 There exist systematic interdependencies between accounts receivable, current assets, and cash holding.

Variables ACR plus CA_OTHER (OWC) interact with CASH (FWC).

Proposal 3 corresponds to WCMP 3. This package contains the variables INV, CASH, and CURR_LIAB. This package is similar to WCMP 1, with the difference that more cash is hoarded (instead of accounts receivables). Keeping inventory low in combination with increased cash holding may represent more strategic considerations, such as creating a high degree of financial flexibility and slack (Han and Qiu 2007; Bates et al. 2009; Kim and Bettis 2014). This may lead to value-enhancing investments that can improve future production and sales. The third proposal is:

Proposal 3 There exist systematic interdependencies between inventory, cash holding, and current liabilities.

Variables CASH minus CURR_LIAB (FWC) interact with INV (OWC).

Proposal 4 reflects WCMP 4. This package contains the variables CA_OTHER, CASH, and CURR_LIAB. Having low holdings in all these components suggests that they are more related to total assets than EBIT. The improved ROA may stem from a general concern of keeping total assets low relative to EBIT.

Proposal 4 There exist systematic interdependencies between other current assets, cash holding, and current liabilities.

Variables CASH minus CURR_LIAB (FWC) interact with CA_OTHER (OWC).

Proposal 5 coincides with WCMP 5. This package contains four variables: INV, ACR, ACP, and CURR_LIAB. The combination of high inventory and low accounts payable may indicate that these firms have a relatively longer cash conversion cycle. This is somewhat surprising, as it normally is recommended to keep the cash conversion cycle low to improve ROA (García-Teruel and MartínezSolano 2007; Baños-Caballero et al. 2010; Gama and Pais 2015; Lyngstadaas and Berg 2016). This may reflect more strategic concerns, such as gaining the trust of the suppliers by making quicker payments and benefitting from discounts by buying in large bulk. The benefit of placing large orders and paying early is that the firm is an attractive customer for its suppliers and the firm can negotiate and realise a better cost of goods sold, that is, improve its EBIT margin. As CURR_LIAB and ACP tie up capital, they should be kept low. This leads to the fifth proposal:

Proposal 5 There exist systematic interdependencies between inventory, accounts receivable, accounts payable, and current liabilities.

Variables INV plus ACR minus ACP (OWC) interact with CURR_LIAB (FWC). This last proposal corresponds to WCMP 11. This package contains the variables INV, ACR, CA_OTHER, and CASH. The combination of high INV and low ACR 
is the same as found in WCMP 5. The difference is that they seem to benefit from more cash. The results may be a combination of increased production and sales, and, simultaneously, keeping total assets relatively low to increase ROA. The sixth proposal is then:

Proposal 6 There exist systematic interdependencies between inventory, accounts receivable, other current assets, and cash holding.

Variables INV plus ACR and CA_OTHER (OWC) interact with CASH (FWC).

Since OWC and FWC are measured differently in the various WCMPs, Table 8 provides a summary of the proposed systematic interdependencies.

\subsubsection{Testing proposed systematic interdependencies}

There are different levels that WCM can be operationalised from a balance sheet perspective, ranging from most aggregate (holistic) levels to looking at specific WCM components (variables). To test systematic interdependencies, a distinction will be made between the kinds of levels to which such interdependencies may exist. Three different levels of interdependencies will be tested. Table 9 shows the most aggregate level of WCM with regard to financial performance. Table 10 summarises the six proposals that have been derived from fsQCA. Table 11 presents the most detailed level of interdependency, examining the pairwise interdependencies between specific WCM components.

Table 9 presents the most aggregate level of operationalising WCM. This operationalisation is aimed at verifying that there exists an interdependency between OWC and FWC at the highest level. Here, it is separated along two paths of operationalising OWC and FWC, denoted as WCM 1 and WCM 2. WCM 1 is in model $1 \mathrm{a}-1 \mathrm{~b}$ and is operationalised as OWC (inventory + accounts receivable + other current assets - accounts payable) + FWC (cash holding - other current liabilities). WCM 2 is in model $2 \mathrm{a}-2 \mathrm{~b}$ and is operationalised as Current assets - Current liabilities. It can be seen from Table 9 that WCMs are statistically and positively interacting with each other with regard to financial performance. This is independent of how WCM is measured (WCM 1 or WCM 2).

The semi-aggregate level used in Table 10 to test the six proposals is lower than that in Table 9. Each of the six proposals consists of just some components from both OWC and FWC, and when combined, they constitute OWC and FWC. For instance, proposal 1 consists of INV and ACR from OWC, and CURR_LIAB from FWC. Each of the WCM components is included separately in the model and also includes an aggregate interaction between OWC (INV + ACR) and FWC (CURR_LIAB) (Table 10, model $1 \mathrm{a}$ and $1 \mathrm{~b}$ ). This is done to test the systematic interdependency between the relevant WCM components in proposal 1. This offers a deeper insight into whether a potential systematic interrelationship exists between specific components of OWC and FWC. This is especially relevant for those groups of firms that use the particular WCMP that is being tested. Table 10 shows that estimating a fixed effect (FE) or random maximum likelihood (RML) 
Table 9 Panel data regressions results $(\mathrm{N}=589)$

\begin{tabular}{|c|c|c|c|c|}
\hline Dep. var.: ROA & $\begin{array}{l}\text { 1a } \\
\text { FE-model }\end{array}$ & $\begin{array}{l}\text { 1b } \\
\text { RML-model }\end{array}$ & $\begin{array}{l}2 \mathrm{a} \\
\text { FE-model }\end{array}$ & $\begin{array}{l}2 \mathrm{~b} \\
\text { RML-model }\end{array}$ \\
\hline OWC & $\begin{array}{l}-0.20^{* * *} \\
(-9.06)\end{array}$ & $\begin{array}{l}-0.17 * * * \\
(-9.46)\end{array}$ & & \\
\hline FWC & $\begin{array}{l}-0.16^{* * *} \\
(-7.25)\end{array}$ & $\begin{array}{l}-0.15 * * * \\
(-6.80)\end{array}$ & & \\
\hline Current assets & & & $\begin{array}{l}-0.14 * * * \\
(-7.02)\end{array}$ & $\begin{array}{l}-0.11 * * * \\
(-7.1)\end{array}$ \\
\hline Current liabilities & & & $\begin{array}{l}-0.10 * * \\
(-2.57)\end{array}$ & $\begin{array}{l}-0.05 \\
(-1.29)\end{array}$ \\
\hline \multicolumn{5}{|l|}{ Firm characteristics } \\
\hline LEV & $\begin{array}{l}-0.01 \\
(-0.21)\end{array}$ & $\begin{array}{l}0.01 \\
(0.29)\end{array}$ & $\begin{array}{l}0.04 \\
(1.63)\end{array}$ & $\begin{array}{l}0.04 * * \\
(2.19)\end{array}$ \\
\hline LIAB_RATIO & $\begin{array}{l}-0.09 * * * \\
(-4.26)\end{array}$ & $\begin{array}{l}-0.09 * * * \\
(-4.97)\end{array}$ & $\begin{array}{l}-0.02 \\
(-0.86)\end{array}$ & $\begin{array}{l}-0.03 \\
(-1.34)\end{array}$ \\
\hline CA_RATIO & $\begin{array}{l}0.21 * * * \\
(7.72)\end{array}$ & $\begin{array}{l}0.16^{* * * *} \\
(6.96)\end{array}$ & $\begin{array}{l}0.16^{* * * *} \\
(5.72)\end{array}$ & $\begin{array}{l}0.12 * * * \\
(4.65)\end{array}$ \\
\hline GROW & $\begin{array}{l}0.03 * * * \\
(4.38)\end{array}$ & $\begin{array}{l}0.02 * * * \\
(3.59)\end{array}$ & $\begin{array}{l}0.02 * * * \\
(4.60)\end{array}$ & $\begin{array}{l}0.02 * * * \\
(3.88)\end{array}$ \\
\hline FINDIST & $\begin{array}{l}0.02 * * * \\
(11.01)\end{array}$ & $\begin{array}{l}0.02 * * * \\
(11.89)\end{array}$ & $\begin{array}{l}0.02 * * * \\
(10.06)\end{array}$ & $\begin{array}{l}0.02 * * * \\
(10.79)\end{array}$ \\
\hline FINCON & $\begin{array}{l}0.07 \\
(1.56)\end{array}$ & $\begin{array}{l}0.16^{* *} \\
(3.29)\end{array}$ & $\begin{array}{l}0.10 * * \\
(2.06)\end{array}$ & $\begin{array}{l}0.19 * * * \\
(3.72)\end{array}$ \\
\hline \multicolumn{5}{|c|}{ Systematic interdependency } \\
\hline $\begin{array}{l}\text { WCM } 1 \\
(\mathrm{OWC} * \mathrm{FWC})\end{array}$ & $\begin{array}{l}0.17 * * * \\
(3.20)\end{array}$ & $\begin{array}{l}0.14 * * \\
(2.54)\end{array}$ & & \\
\hline $\begin{array}{l}\text { WCM } 2 \\
\text { (Current assets * Current } \\
\text { liabilities) }\end{array}$ & & & $\begin{array}{l}0.10 * * \\
(2.55)\end{array}$ & $\begin{array}{l}0.05^{*} \\
(1.65)\end{array}$ \\
\hline Constant & $\begin{array}{l}0.04 * * \\
(2.00)\end{array}$ & $\begin{array}{l}0.04 * * * \\
(2.54)\end{array}$ & $\begin{array}{l}0.04 * * \\
(2.01)\end{array}$ & $\begin{array}{l}0.04 * * * \\
(2.54)\end{array}$ \\
\hline Year fixed? & Yes & & & \\
\hline Obs. & 4255 & & & \\
\hline $\mathrm{R}^{2}$ overall & 0.36 & & 0.37 & \\
\hline
\end{tabular}

Two types of panel data regressions are run. First is FE panel data regression with year dummies and cluster robust standard errors. The second regression is RML panel data regression with year dummies and bootstrapped standard errors. ROA is the dependent variable. Model 1a and 1b measures WCM $1=$ OWC + FWC. Model 2a and 2b measures WCM $2=$ Current assets - Current liabilities. LEV is leverage; LIAB_RATIO is current liabilities ratio; CA_RATIO is current asset ratio; GROW is firm growth; FINDIST is financial distress measured by Altman Z-score; FINCON is financial constraint. Obs. is the number of observed firm years. Variable coefficients are reported with $t$-statistics in parenthesis for FEregression and $z$-statistics for RML regressions. Variables with $* * *$, and $* * *$ denote significance at the $10 \%, 5 \%$, and $1 \%$ levels, respectively

panel data regression yields similar results. The OWC and FWC seem to form a complementary system, as all six proposals are statistically significant. That said, proposal 3 has the weakest relationship between OWC and FWC with financial 


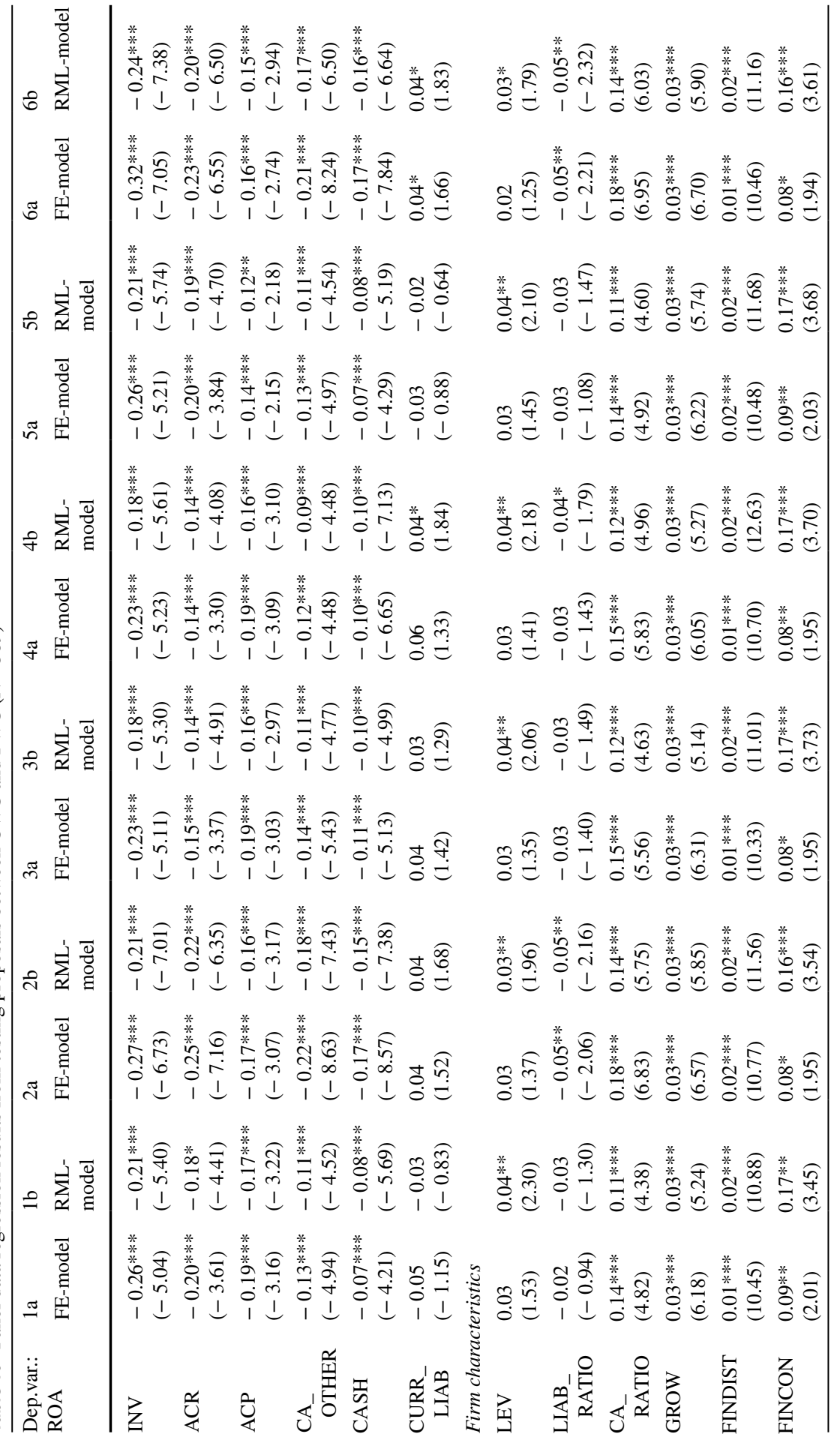




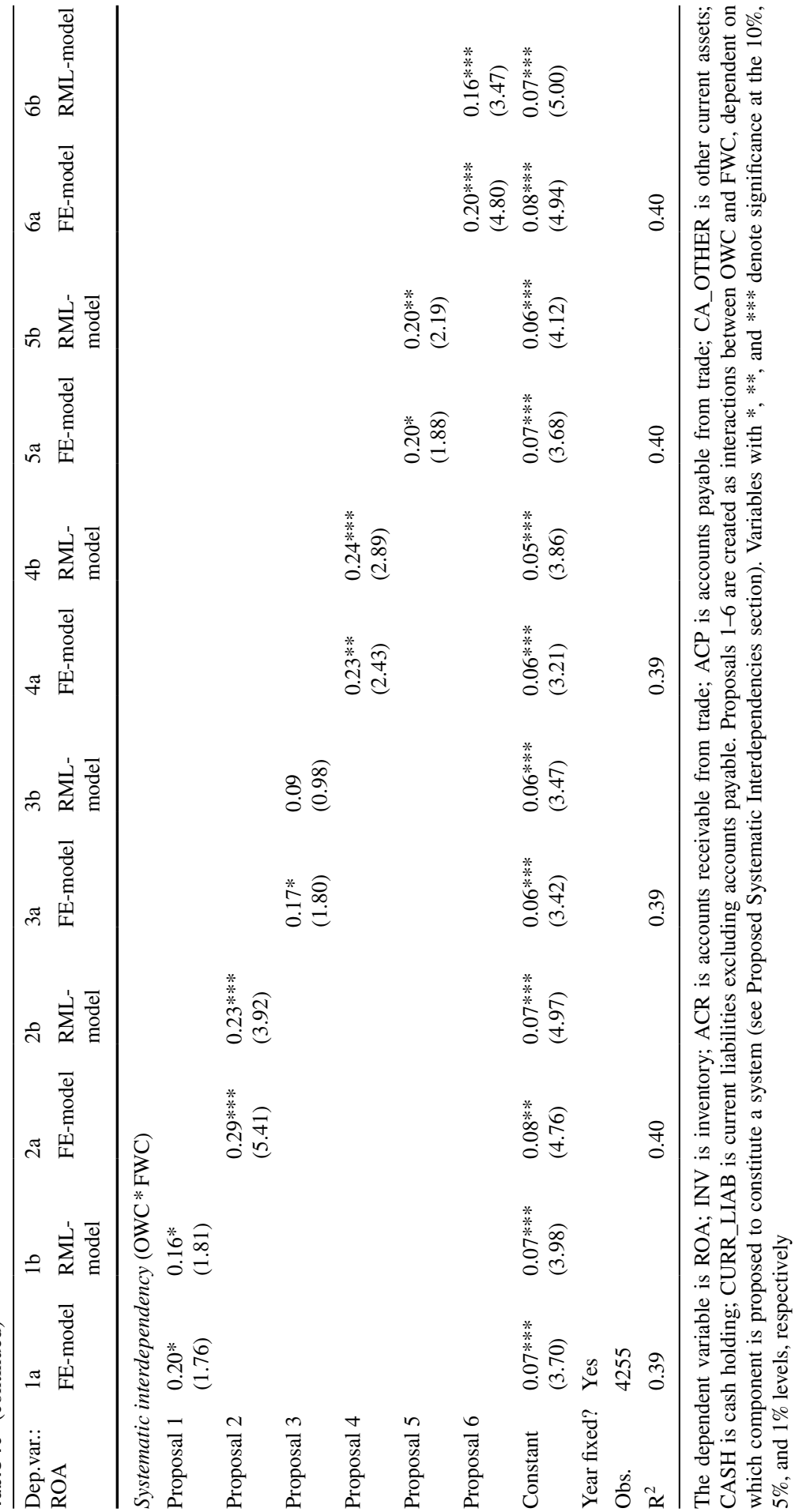


Table 11 Testing pairwise systematic interdependencies within and between OWC and FWC

\begin{tabular}{|c|c|c|c|}
\hline Dep. var.: ROA & Proposal & $\begin{array}{l}\text { la } \\
\text { FE-model }\end{array}$ & $\begin{array}{l}\text { lb } \\
\text { RML-model }\end{array}$ \\
\hline \multicolumn{4}{|l|}{$\begin{array}{l}\text { Within } \\
\text { OWC }\end{array}$} \\
\hline INV*ACR & $1 ; 5 ; 6$ & $\begin{array}{l}0.71 * * \\
(2.43)\end{array}$ & $\begin{array}{l}0.52 * * \\
(2.18)\end{array}$ \\
\hline INV*ACP & 5 & $\begin{array}{l}1.03^{*} \\
(1.78)\end{array}$ & $\begin{array}{l}0.76 \\
(1.53)\end{array}$ \\
\hline ACR*CA_OTHER & $2 ; 6$ & $\begin{array}{l}0.63 * * \\
(2.17)\end{array}$ & $\begin{array}{l}0.39 \\
(1.55)\end{array}$ \\
\hline $\mathrm{ACR} * \mathrm{ACP}$ & 5 & $\begin{array}{l}1.18 * * * \\
(2.60)\end{array}$ & $\begin{array}{l}0.81 * * \\
(1.92)\end{array}$ \\
\hline INV*CA_OTHER & 6 & $\begin{array}{l}0.74 * * \\
(2.37)\end{array}$ & $\begin{array}{l}0.59 * * \\
(2.09)\end{array}$ \\
\hline \multicolumn{4}{|l|}{$F W C$} \\
\hline CASH*CURR_LIAB & $3 ; 4$ & $\begin{array}{l}0.08 * \\
(1.76)\end{array}$ & $\begin{array}{l}0.02 \\
(0.56)\end{array}$ \\
\hline \multicolumn{4}{|c|}{ Between $O W C$ and $F W C$} \\
\hline INV*CURR_LIAB & $1 ; 3 ; 5$ & $\begin{array}{l}0.44 * * * \\
(2.75)\end{array}$ & $\begin{array}{l}0.42 * * * \\
(3.35)\end{array}$ \\
\hline ACR*CURR_LIAB & $1 ; 5$ & $\begin{array}{l}0.11 \\
(0.64)\end{array}$ & $\begin{array}{l}0.06 \\
(0.37)\end{array}$ \\
\hline CA_OTHER*CASH & $2 ; 4 ; 6$ & $\begin{array}{l}0.34 * * * \\
(3.76)\end{array}$ & $\begin{array}{l}0.29 * * * \\
(3.56)\end{array}$ \\
\hline INV*CASH & $3 ; 6$ & $\begin{array}{l}0.27 * * * \\
(2.62)\end{array}$ & $\begin{array}{l}0.20 * \\
(1.92)\end{array}$ \\
\hline $\mathrm{ACR} * \mathrm{CASH}$ & $2 ; 6$ & $\begin{array}{l}0.32 * * * \\
(4.00)\end{array}$ & $\begin{array}{l}0.24 * * * \\
(2.82)\end{array}$ \\
\hline ACP*CURR_LIAB & 5 & $\begin{array}{l}0.11 \\
(0.64)\end{array}$ & $\begin{array}{l}0.06 \\
(0.40)\end{array}$ \\
\hline Year fixed? & & Yes & \\
\hline Obs. & & 4255 & \\
\hline
\end{tabular}

First column shows pairwise interdependencies between specific WCM components. Second column shows the proposal (1-6) from which the pairwise interdependencies are derived from. The third and fourth columns show the panel data regression estimates (FEmodel and RML-model), with each row and cell representing an estimated model. The same model is recomputed by altering the included potential interaction term between WCM components that is of interest. Variables with $*, * *$, and $* * *$ denote significance at the $10 \%, 5 \%$, and $1 \%$ levels, respectively

performance. The strongest effects from the combinations of OWC and FWC seem to come from proposals 2,4 , and 6 .

What could be noted is that the net effect from CURR_LIAB is mostly not significant in different estimations of models in Table 10. However, the proposals that contain CURR_LIAB as a part of FWC have a statistically significant effect. 
This may indicate that CURR_LIAB is important when viewed as a part of a system with several other WCM components, although it is not statistically significant independently.

Table 11 presents pairwise systematic interdependencies between specific WCM components. This is done by conducting pairwise comparisons, either within or between specific components of OWC and FWC. This is the lowest possible level of interdependency. While the proposals may not be statistically significant, it may be that some of the components are still interdependent. This is also relevant from the managerial point of view because it signals which components need to be seen as parts of the same decision-making and control process. Since the same pairwise combinations of WCM components are represented in different proposals, the second column in Table 11 indicates the proposal from which the pairwise interrelationships are derived. Table 11 contains the same control variables as Table 10, but only interaction effects between the pairwise combinations are reported to conserve space. Each cell in columns 3 and 4 in Table 11 equals a separate regression estimation. From Table 11, it may be noted that while several components from OWC and FWC may combine to form a system, they are not necessarily pairwise interdependent. Looking at CURR_LIAB, the systematic interdependency is not statistically significant when running in pairwise interaction within FWC (between CASH and CURR_LIAB), or with other components of OWC (ACR and ACP). One possible reason for this is that the type of systematic interdependency occurs at the highest (Table 9) and semi-aggregate (Table 10) levels, while the lowest level is mostly not supported. This may indicate that the effect from OWC and FWC on financial performance is created when they are combined into more holistic systems, as suggested by the WCMPs.

The main impression is that the level that WCM is studied affects our understanding of it as a decision-making and control system. WCM consists of both loosely connected components, to a more all-embracing system of interdependencies. That said, it could be that different functional forms exist at a lower level which is not captured in the estimations, resulting in non-significant effect. It could also be that the specific pairwise effects with variables such as CURR_LIAB are only valid for those group of firms that use the WCMPs that contains this component.

\section{Discussion and conclusion}

\subsection{Discussion}

Two research questions informed this study. The first research question was the following: How do manufacturing firms combine OWC and FWC into effective WCMPs that contribute to financial performance? The fsQCA results from Table 6 show 11 packages (configurations) that effectively achieve high financial performance. However, out of the 11 packages, six packages show the greatest empirical importance. This is based on the assessment of the fsQCA solutions and unique coverage derived from each WCMP. The six packages were used for developing six proposals to show how financial performance is affected by systematic 
interdependencies that exist among the components within and between OWC and FWC. Table 10 shows that while all six proposals were statistically significant, proposal 3 was only weakly supported. The six proposals seem to confirm that there are systematic interdependencies between OWC and FWC that act in a complementary manner to affect financial performance. As can be seen in Table 6, out of the six components constituting WCM (i.e. inventory, accounts receivable, cash holding, other current assets, accounts payable, and other current liabilities), accounts payable is the component that is identified as a core condition in the fewest of the WCMPs. This suggest that in order to achieve high financial performance, accounts payable from WCM seem to have the least empirical importance according to the fsQCA solutions. One possible reason is that there are few gains to be derived from accounts payable compared to competitors. For instance, if there exist strong industry norms for suppliers who offer credit terms, then there is little competitive advantage to be gained as all firms compete on equal supplier terms. Looking at other WCM components, such as cash holding, there is potentially more flexibility in conducting cash management. Some firms may maintain the lowest possible cash holding, while, at the same time, trying to ensure that short-term obligations are met. Other firms may use cash holding more strategically, such as for managing fluctuations in demand, or to provide investment for future growth. Such differences in the conduct of cash holding management can distinguish the firms that achieve high financial performance from that do not achieve such performance.

Looking closer at each proposal presented in Table 8 and the estimated results in Table 10, there seem to be several WCM tactics that can enhance financial performance. WCMP 1 in Table 6 corresponds to proposal 1 in Table 8. Keeping inventory low decreases invested capital at a given time but seem to offer relatively longer customer trade credit. From Table 7, it is apparent that these firms have WCM close to one-third of their net sales. Thus, they have a relatively high share of total WC in their balance sheets.

WCMP 2 in Table 6 corresponds to proposal 2 in Table 8. These firms pursue an even more conservative WCM approach, as Table 7 shows they have the largest share of WC against net sales (approximately 40\%). These firms held on average almost one-quarter of net sales in net cash holding (FWC), which may be because they use cash holding to gain strategic flexibility. However, it is not possible to identify the reason for cash holding. These firms may be the ones with high growth potential, or they may have sold assets and kept a large cash holding in their balance sheet. The low levels of ACR may indicate that even though their total WC is relatively high, the firms belonging to this group pursue a more aggressive approach for collecting customer receivables. It may also be that these firms use factoring or similar approaches to avoid too much capital invested in ACR.

WCMP 3 in Table 6 corresponds to proposal 3 in Table 8. As can be seen from Table 7, these firms also seem to be holding higher levels of net cash. Their motive in having high cash holding may be to avoid the overcapitalisation of business operations.

WCMP 4 in Table 6 coincides with proposal 4 in Table 8. What is interesting is that these firms seem to benefit from components other than what is typically associated with WCM, such as the components that form the cash conversion 
cycle (inventory, accounts receivable, and accounts payable). As can be seen in Table 7, these firms keep one of the lowest net cash holdings as compared to the other groups. Based on the fsQCA solution in Table 6, this seems to be empirically important for achieving high financial performance. While cash holding may offer a strategic opportunity, decreasing total assets by keeping OWC low may also contribute to the increased financial performance. WCMP 5 from Table 6 corresponds with proposal 5 from Table 8. WCMP 5 seems to benefit from exactly those components that are involved in the cash conversion cycle. Table 7 shows that OWC is relatively high compared to other groups (OWC constitutes approximately $27 \%$ of net sales). This may facilitate production and sales, as they can both attract customers and achieve purchase discounts from large orders. At the same time, FWC is relatively low compared to other groups (FWC constitute approximately $-4 \%$ of net sales), indicating that these firms try to keep their current liabilities low. This is not necessarily a problem because they may be able to quickly convert their OWC into cash when required for meeting short-term obligations. These firms seem to not hold cash for strategic flexibility but rather focus on stimulating production and sales by their higher levels of inventory and accounts receivable. Since these firms achieve high financial performance, the higher level of inventory does not seem to be a problem (i.e. these firms do not suffer substantial losses from unsold products and goods). WCMP 11 from Table 6 coincides with proposal 6 from Table 8. WCMP 11 is somewhat similar to WCMP 5, but cash holding seems to have higher empirical importance in WCMP 11. These firms seem to be using a combination of tactics. Relatively higher levels of inventory may facilitate production and sales, while relatively lower levels of accounts receivable generate cash holding. This may be used both for meeting short-term obligations and creating future growth opportunities.

Looking at interdependencies within and between OWC and FWC in Table 11, the results vary. This may indicate that components in the different WCMPs form holistic systems but at different levels. While some systematic interdependencies exist at the lower levels (two-way interaction between variables), there are also the ones existing at a higher level (packages of OWC and FWC).

Examining the within interdependencies among components of OWC and FWC, it can be seen from Table 11 that inventory and accounts receivable are strongly complementary. This is not surprising because they are the two main components in the cash conversion cycle. Although statistically significant and complementary, the relationship between inventory and accounts payable is less clear. One possible reason is that the inventory level is related to customer sales while procuring inventory is related to suppliers. Customer sales and suppliers are two different parts of the supply chain streams and they operate independently of each other. However, accounts receivable and accounts payable are statistically significant and strongly complementary. This may indicate that firms do match their policies related to receivables and payables because the two components affect the self-financing period in the cash conversion cycle. What is perhaps surprising is the weak relationship between cash holding and current liabilities (excluding accounts payable). The challenge is that the measure for current liabilities contains more information than just short-term debt/bank loans. For instance, a large tax-deferred liability could create large fluctuations among firms in this variable. This makes the variable potentially 'noisy', which may explain its loss of significance. 
Since CURR_LIAB captures current liabilities that are not accounts payable, it constitutes a relatively large share when scaled by net sales. This can explain why it is identified as a core condition in most of the WCMPs.

Looking at interdependencies between components of OWC and FWC, cash holding seems to have the strongest complementary relationship with the other components in OWC. This lends more support for the conclusion that cash holding is a complement rather than a substitute for other sources of financing (Biais and Gollier 1997; Jain 2001). A possible explanation is that cash holding creates financial flexibility and slack that can be used in value-enhancing ways. As such, cash holding seems to have a strategic value (Bates et al. 2009; Han and Qiu 2007; Kim and Bettis 2014).

Three general remarks can be made regarding the fsQCA and panel data regression results. First, management accounting research has often assumed unifinality (Gerdin and Greve 2004). However, the different packages illustrate that there are various and equal ways to achieve high financial performance. Although components of OWC and FWC may be shown to be statistically significant individually, they do not necessarily contribute equally to financial performance when combined into a package. Some are more important than others in a given package. This distinguishes components as being core or redundant (Gerdin and Greve 2004; Bedford et al. 2016).

Second, identifying WCMPs is not necessarily the same as stating they are working capital management systems. While the six proposed systems were statistically significant at the most aggregate level, there were variations at lower levels of systematic interdependency.

Third, the level of systematic interdependency seem to vary. This may also shed some light on the challenges of relying solely on net-effect regression methods. Selecting and running regression models with only a few key variables can potentially omit relationship existing between variables at a higher level (Ragin 2006a; Woodside 2013). It is understandable to not run all possible two- or three-way interactions in the same model, as it has the potential of creating problem of multicollinearity. This can result in $p$-values changing from significant to non-significant, or coefficients changing direction (Woodside 2013; Huang and Huarng 2015). That being said, this study shows that combining fsQCA and panel data regression is useful because the two methods may, together and complementarily, add methodological strength. fsQCA can indicate which WCMPs exist and where to look for systems. Panel data regression can detect the strength and direction of the systematic interdependencies.

\subsection{Robustness tests}

Robustness testing analyses the uncertainty of models and tests whether the estimated effects of interest are sensitive to changes in model specifications (Neumayer and Plümper 2017). The main idea is that uncertainty decreases if the robustness test models find the same or similar effects or point estimates from the analysis. Robustness checks become a methodological tool for increasing the validity of inferences (Neumayer and Plümper 2017).

Robustness testing consists of four steps. First, the optimal specification must be defined, which becomes the baseline model. Thereafter, potentially arbitrary 
assumptions about the baseline model must be identified because they could be potentially replaced by alternative model specifications. The alternative model specifications are changed in their assumptions, one at a time, and these are called the robustness test models. The estimated effects of the alternative model specification are compared with the estimated effects of the baseline model. This indicates the degree of robustness in terms of how much baseline and alternative models coincide with each other (Neumayer and Plümper 2017).

The types of robustness tests conducted in this paper are structured permutation tests and model variation tests (Neumayer and Plümper 2017). Structured permutation tests change specification assumptions repeatedly (such as sensitivity tests). Changes in the specification are not random variations but based on a rule on how much a parameter may be increased/decreased. The structured permutation tests can indicate how much a model specification has to change before the effect of interest becomes not valid, i.e. the boundaries of the observed effects in the baseline model (Neumayer and Plümper 2017).

Model variation tests change one model specification assumptions (such as about operationalisation or sample selection) and replace it with an alternative assumption. The model variation test is perhaps more suited when assessing model uncertainty with fewer discrete plausible alternatives (Neumayer and Plümper 2017).

fsQCA does a structured permutation test by conducting a sensitivity analysis of key parameters when performing a fsQCA. As the researcher's choices affect the analysis and results, it is important to verify that the identified effects are not arbitrary upon researcher choices. Panel data regression uses a model variation test by changing sample selection (from unbalanced to balanced panel data set), and specification of the independent and dependent variables. The independent variable is altered by changing how WCM is operationalised. The dependent variable is operationalised as a form of liquidity measure rather than a profitability measure. This is based on how liquidity and profitability are two sub-dimensions of accounting-based financial performance measures. By showing the robustness across various dimensions of financial performance, it is possible to increase the validity of the financial performance concept (Neumayer and Plümper 2017).

\subsubsection{Robustness test of fuzzy set qualitative comparative analysis}

There exist several 'best practice guides' on fsQCA aimed at enabling researchers to add robustness to the fsQCA solutions (Ragin 2008; Bedford and Sandelin 2015; Greckhamer et al. 2018). The proposed robustness tests can be summarised as conducting sensitivity analysis on a) frequency threshold, b) consistency threshold, c) negation of outcome, and d) calibration procedure for assigning membership scores.

Table 12 summarizes the sensitivity analysis on fsQCA. The sensitivity analysis is conducted by changing one parameter at a time while holding the others constant. The intermediate solutions are reported, as these are also reported in Table 6. This makes it possible to compare solutions, as they are based on the same set-theoretic assumptions.

The frequency threshold indicates the minimum frequency of empirical cases that produces the outcome of interest, to be seen as valid. The frequency threshold is 

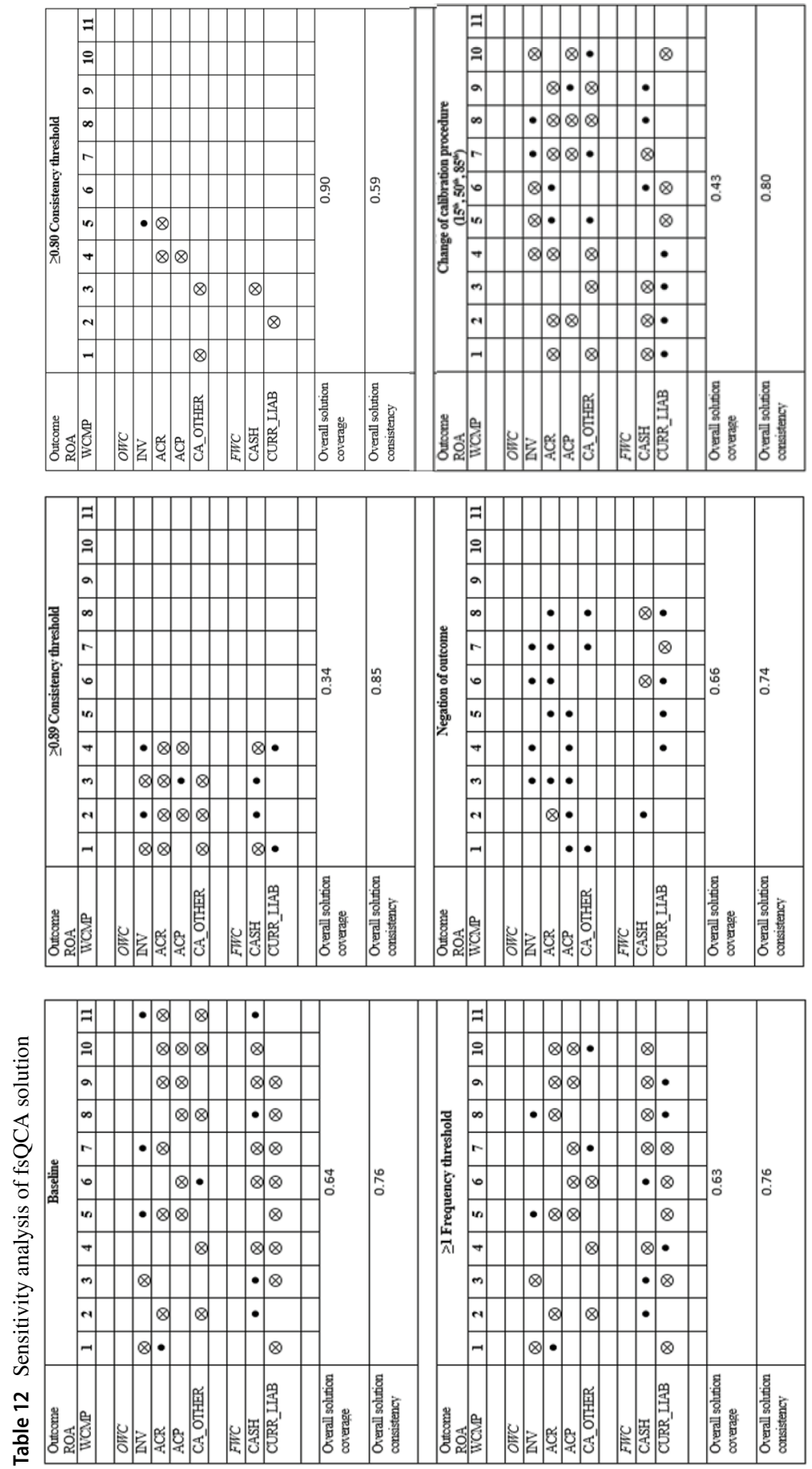
changed from a minimum of three empirical cases to one. This affects the fsQCA solution minimally. This is also reflected by the almost identical solution coverage and consistency. This suggests that the viability of causal combinations of conditions remains unchanged when changing the frequency threshold.

The consistency threshold is used for distinguishing causal combinations of conditions that are able to produce the presence of the outcome of interest, from those that are not. But achieving high consistency is not the same as achieving high coverage. Usually, there is a trade-off (Ragin 2008). This is also evident when changing the consistency threshold to either $\geq 0.89$ or $\geq 0.80$. Increasing the consistency threshold from baseline $\geq 0.85$ to $\geq 0.89$ means that causal combinations must, to a higher degree, consistently produce the presence of the outcome of interest. This is a more conservative approach. In this case, there are some complex WCMP configurations that consistently lead to the presence of high financial performance. However, low coverage suggests that relatively few firms have exactly those configurations. In other words, low coverage suggests low empirical relevance or importance due to narrowly formulated configurations. When decreasing the consistency threshold from baseline to $\geq 0.85$ to $\geq 0.80$, the threshold becomes more liberal. As a result, the overall consistency decreases, but coverage increases. This indicates that when including more firms in the solutions, there is an increase in how much variation of high financial performance is totally explained by the firms. However, the fsQCA solutions lead inconsistently to high financial performance, making it difficult to make strong causal claims. From a practical point of view, it also makes less logical sense to suggest that one should focus on only one of the WCM components in the simplest WCMPs.

The negated sets are the same as saying that high financial performance does not occur (absence of outcome of interest). From covariance-based research, a typical assumption is a symmetrical relationship between variables. For instance, finding that high levels of inventory lead to high financial performance implies that the opposite is true as well (all else equal). This is not necessarily the case in fsQCA, as there may exist asymmetric relationships. For instance, finding that high levels of inventory lead to high financial performance does not say anything (explicit or implicit) about what happens if you have low levels of inventory with regard to financial performance. In some cases, low levels of inventory may also be important, but that depends on the complex relationship with other WCM components on how they as a package and system contribute to high financial performance.

Two different analyses were conducted to assess the negation of outcome (i.e. low financial performance). ${ }^{12}$ The first analysis is about evaluating causal necessity. None of the conditions were found to be necessary for producing low financial performance. Put differently, the conclusion is that there is no single condition that is represented in all WCMPs that leads to low financial performance. The second

\footnotetext{
12 While Ragin (2008) would most likely reject the notion of using "low financial performance" as the negated outcome, this is used to denote that "low" is relatively to other firms in the data sample. It is not claimed that what is low or high is true in absolute sense, and offer just more analytical convenience.
} 
analysis is about evaluating the configurational structure of the negated WCMPs. This could provide a deeper insight into the (a)symmetric properties of the relationship between WCMPs and financial performance. This is important as it becomes more challenging to assess statistical significance if there is no symmetrical relationship between variables. The negation of outcome seems to support a somewhat symmetric relationship, as the general picture is that an increased level of OWC and FWC is associated with lower ROA. Looking at Table 7, those firms having low financial performance (net negation of outcome) seem to especially accumulate more OWC compared to those firms achieving high financial performance.

Changing the calibration procedure does create some changes in the solutions. In general, the solutions become more complex, which comes with the cost of decreased coverage. The decreased overall solution coverage indicates low empirical relevance, as the solutions are only used by a few firms. Again, the trade-off seems to be more balanced by using the assumptions in the baseline model about thresholds and consistency level.

\subsubsection{Robustness panel data regression}

Several different robustness tests were conducted for the panel data regression. Proposals tested in Table 10 acted as baseline models. Table 10 is important as it contains the proposals derived from the fsQCA.

Table 13 uses the same baseline models from Table 10 for each proposal. The difference is that a strictly balanced data sample is used, with 383 unique firms surviving in the entire period between 2012 and 2019. The rationale is that survival could be argued to represent the strongest indication of financial performance, compared to those firms not surviving over time (Fischer and Pollock 2004). While proposals 1-2 and 5-6 were confirmed similarly to Table 10, proposals 3 and 4 were not statistically supported (model $3 \mathrm{a}-4 \mathrm{~b}$ ). However, using a balanced data set may yield a higher risk of survivorship bias and create measurement error (Hallahan and Faff 2001). As such, a more cautious reading of (not) significant effects might be warranted.

Second, a different specification of WCM was used compared to Table 10, defining $\mathrm{WC}$ as the difference between current assets and current liabilities. This shifts the placement between OWC and FWC from Table 8, as accounts payable is now a part of FWC and cash holding is a part of OWC. The consequence is that proposal 3-5 in Table 10 is measured differently, creating changes in how the systematic interdependencies are tested. It does not alter how OWC and FWC are measured in proposal 1-2 and $6,{ }^{13}$ so they are not tested again. Although the results are not reported here, proposal 3-5 was statistically significant at the $1 \%$ level (both FEregression and RML-regression) when using this altered specification of WCM. This suggests that the results from Table 10 are robust for changes made in how WCM is defined, i.e. it increases concept validity (Neumayer and Plümper 2017).

\footnotetext{
13 Proposal 6 now contains only OWC components, so it is not possible to run interactions with FWC.
} 


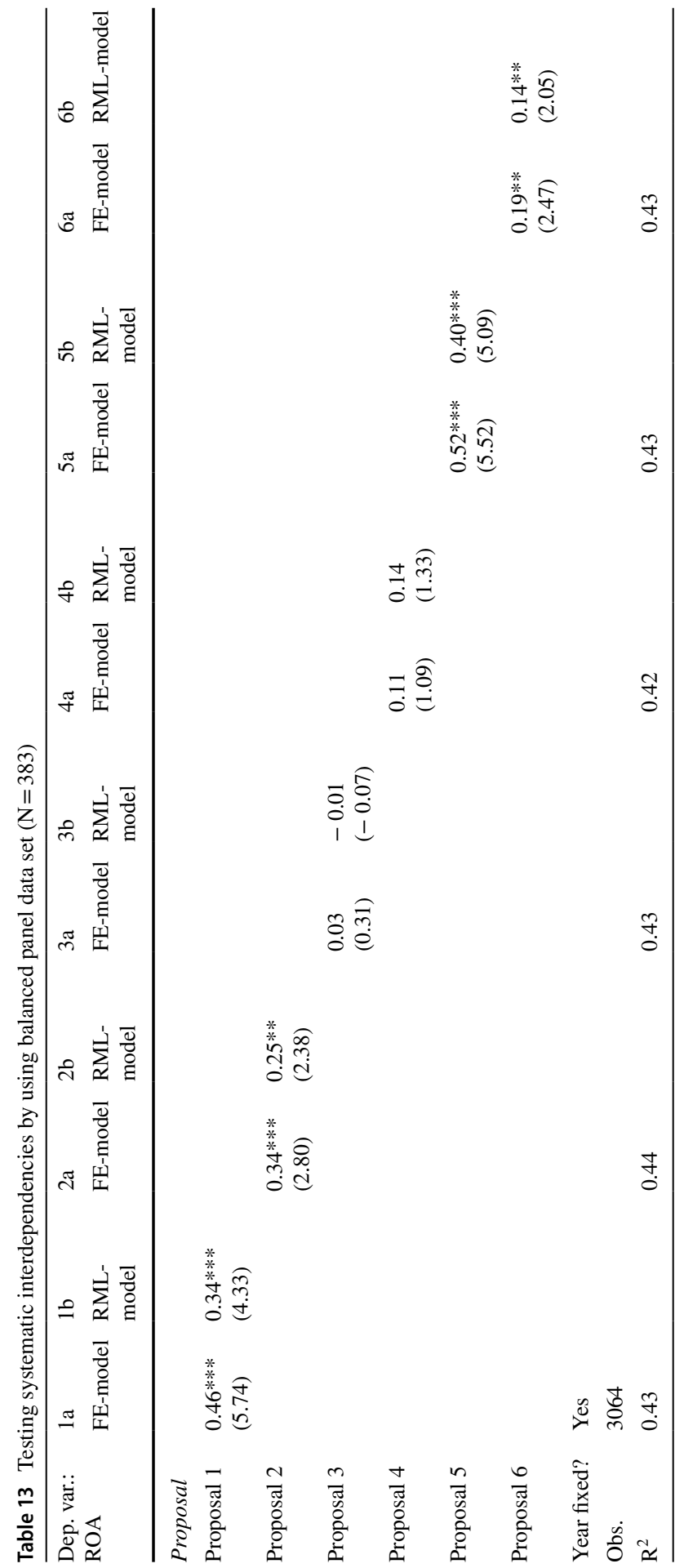




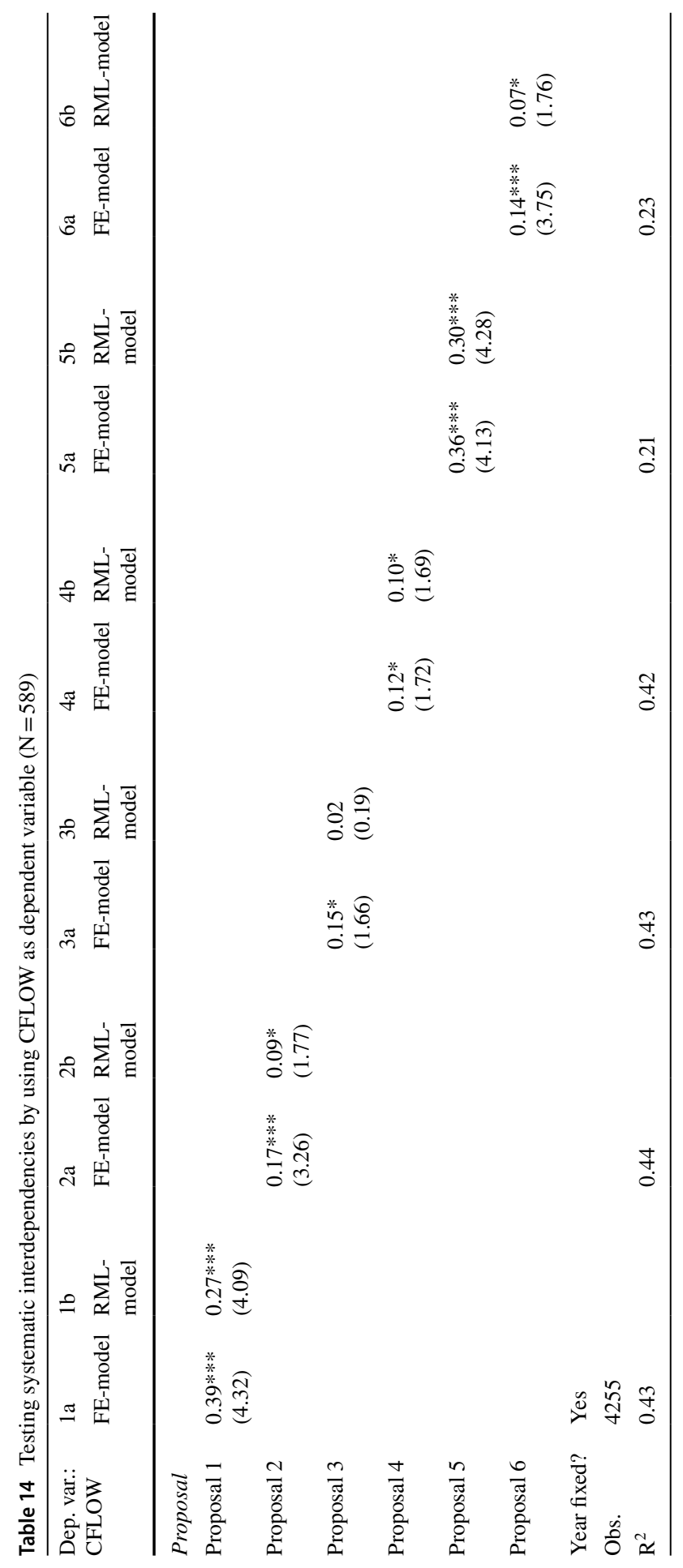


The last test was conducted by using a different outcome variable. This is shown in Table 14. Do the same systematic interdependencies exist for affecting liquidity or do they only affect profitability? Liquidity was measured as CFLOW = net cash flow from operating activities/total assets. Using the same baseline model from Table 10 for testing each proposal, the results were approximately the same. This may suggest that profitability and liquidity are two related dimensions of financial performance when using accounting returns (Hamann et al. 2013). In other words, the complementary effect between OWC and FWC affects both profitability and liquidity.

A limitation of the robustness tests is that the results only apply to accounting returns. For instance, using growth (such as growth in sales or total assets) as an outcome variable may yield different results. The reason is that growth is not necessarily the same as accounting returns. Growth may come at the expense of profitability and vice versa (Combs et al. 2005). This suggests that the results in this paper may not be valid for other dimensions of financial performance.

\subsection{Managerial implications}

Managers should be aware that there is no one-size-fits-all solution to WCM. Some firms keep more/less of either OWC or FWC while still achieving high financial performance. The differences in OWC and FWC may be viewed in terms of finding packages that create a good fit for the given firm. A common denominator is that OWC lies between $14 \%$ and $27 \%$ of net sales, while FWC lies between $-15 \%$ and $-25 \%$ of net sales. This may indicate that these firms have found the right balance between risk, liquidity, and return.

Looking closer at each component in OWC and FWC, some differences become evident in the relative importance in a WCMP. Inventory, accounts receivable, other current assets, and current liabilities are the most common components that managers should pay particular attention to. While some firms seem to benefit from a just-in-case inventory strategy (WCMP 5 and 11), others benefit from a just-in-time inventory strategy (WCMP 1 and 3). However, a component cannot be seen in isolation, as every component is shown to be systematically interdependent with other working capital components.

More surprising is that accounts payable (trade) is a core condition in only one WCPM. One possible reason is that industry norms exist for the types of supplier terms and agreements offered to buyers. This can indicate that there is less opportunity to distinguish oneself from competitors by achieving substantially better terms or agreements. Another reason may be that all firms actively manage their supplier relationship with substantial resources, making it difficult to gain a competitive advantage.

\subsection{Limitations and directions for future research}

While the study offers empirical, methodological, and managerial contributions, there are some limitations that must be acknowledged. First, generalising from the manufacturing sector to other sectors must be done cautiously. One of the key ideas 
behind fsQCA is to maintain the integrity of each empirical case. This mainly limits the findings to empirical cases in the manufacturing sector among listed firms. For instance, in other sectors such as retail, keeping larger inventory volumes comes with high operational risk. Seasonal sales, trends, and competitor dynamics change rapidly, making buffer inventory rapidly outdated and unsold. That being said, there are also some similarities. Both manufacturing and retail sectors use accounts receivable and accounts payable, although for different reasons. Jain (2001) suggests that receivables and payables are typically offered in sectors with the supply side more concentrated compared to the demand side, i.e. retail sector, or in sectors with high monitoring costs, i.e. manufacturing sector. However, accounts receivable is most likely less used in the retail sector as direct payments are common. This implies that there is a higher operational risk of offering customers trade credit in the manufacturing sector. For instance, if some of the largest customers in the manufacturing sector do not pay according to terms and agreements, there may be severe consequences for liquidity and solidity. The probability of default may explain why accounts receivable is identified as a core condition in four out of six effective WCMPs and in most cases suggested to be kept low. The interrelationship between inventory, accounts receivable, and accounts payable can be different among various sectors. For instance, online retail is not unfamiliar with having a negative cash conversion cycle (such as Amazon), while this seems to be more uncommon in the manufacturing sector.

The accumulation of cash is found to be beneficial for high financial performance in half of the effective WCMPs. This is contrary to the assumption of cash as a potentially unproductive resource, as argued by Mun and Jang (2015) in the service sector. It is difficult to assess why cash holding seems desirable in the manufacturing sector. One possible argument is based on the precautionary motive (Bates et al. 2009). ${ }^{14}$

It is also difficult to move from exploratory to explanatory arguments about WCM as fsQCA moves quickly into overwhelmingly complex solutions. For instance, it is possible to split inventory in OWC into its constitutive parts (raw, work in progress, finished, other). However, adding just one more condition would increase the theoretical solutions from 64 to 128 .

The methodological combination of fsQCA and panel data regression is not without its challenges; fsQCA is mostly used for cross-sectional analysis and is preoccupied with analysis of either high or low outcome. This is based on the assumption of asymmetric effects. Panel data regressions are perhaps more common for detecting linear net effects, and as such, they may not necessarily support fsQCA solutions. Future research can benefit from using even larger data sets, as each group in the fsQCA solution could be large enough for testing specific proposals. Since specific proposals is relevant for specific groups of firms, this can make it possible to isolate the firms where there exist systematic interdependencies.

\footnotetext{
14 It is not possible to rule out other explanations, such as active tax minimisation strategy (Faulkender et al. 2019). Financial tax strategies can be relevant on a cross-sectorial basis, but this was not tested in this study.
} 
Lastly, it is difficult to state both the temporal dynamics and causal direction of effects between WCM and financial performance. The temporal dynamic effects could either be immediate, delayed or expected (Neumayer and Plümper 2017). In this case, since WCM commonly has a short-term orientation, it is modelled as an immediate effect with a beginning and end in the same period as financial performance. The onset (immediate, delayed, or expected effects), duration, and evolution of the causal relationship between WCM and financial performance could be different in different periods, creating multiple temporal functional forms (Neumayer and Plümper 2017). In addition, it is not possible to state anything about reverse causality or bidirectionality. It could be that superior financial performing firms can establish better WC terms, creating a more efficient WCM, thus leading to further financial gains. This indicates that there is a lot of future research opportunities for exploring the complexity of WCM.

Funding Open Access funding provided by Norwegian Business School.

Open Access This article is licensed under a Creative Commons Attribution 4.0 International License, which permits use, sharing, adaptation, distribution and reproduction in any medium or format, as long as you give appropriate credit to the original author(s) and the source, provide a link to the Creative Commons licence, and indicate if changes were made. The images or other third party material in this article are included in the article's Creative Commons licence, unless indicated otherwise in a credit line to the material. If material is not included in the article's Creative Commons licence and your intended use is not permitted by statutory regulation or exceeds the permitted use, you will need to obtain permission directly from the copyright holder. To view a copy of this licence, visit http://creativecommons.org/licen ses/by/4.0/.

\section{Appendix}

\section{Consistency, coverage, and minimisation procedure in fsQCA}

\section{Consistency}

Consistency is calculated by dividing the number of cases with $x_{i} \geq=y_{i}$ by the number of all cases with $\mathrm{x}_{\mathrm{i}}>0 . \mathrm{X}$ is the membership score in the condition and $\mathrm{Y}$ is the membership score in the outcome. The term 'min' indicates the selection of the lower of the two values. The closer the subset is to equal the outcome, the closer the consistency score will be to 1.0. A score equal to 1.0 indicates high consistency of the statement that $\mathrm{X}$ is sufficient for achieving $\mathrm{Y}$ (this equals falling above the main diagonal line in an $\mathrm{x}-\mathrm{y}$ plot) (Ragin 2008).

$$
\text { Consistency }=\frac{\sum\left(\min \left(\mathrm{X}_{\mathrm{i}} \mathrm{Y}_{\mathrm{i}}\right)\right)}{\sum \mathrm{X}_{\mathrm{i}}}
$$




\section{Coverage}

While bearing resemblance with $\mathrm{R}^{2}$, coverage is asymmetric. The amount of variation explained holds neither for the inverse relationship nor between the condition and outcome (Fiss et al. 2013b, p. 194). Coverage is found by summing up the number of cases that display a specific condition and dividing it by the number of cases to be explained (presence of a given outcome). The coverage is similar to the measure of consistency, just substituting X1 with Y1 in the denominator (Ragin 2008).

$$
\text { Consistency }=\frac{\sum\left(\min \left(\mathrm{X}_{\mathrm{i}} \mathrm{Y}_{\mathrm{i}}\right)\right)}{\sum \mathrm{Y}_{\mathrm{i}}}
$$

\section{Minimisation procedure}

Boolean minimisation reduces long and complex expressions into a more elegant solution. For instance, two solutions can differ in only one condition with regard to producing the outcome. We can assume that the two solutions are $\mathrm{A} * \mathrm{~B} \rightarrow \mathrm{Y}$ and $\mathrm{A}^{*} \sim \mathrm{B} \rightarrow \mathrm{Y}$. A and $\mathrm{B}$ are the conditions and $\mathrm{Y}$ is the outcome. Here, the presence of condition $\mathrm{A}$ is important in both solutions. However, whether condition $\mathrm{B}$ is present (B) or absent $(\sim \mathrm{B})$ is irrelevant. As long as condition A is present, it seems that condition $\mathrm{B}$ is not important in producing the outcome (Y). A more elegant and simpler solution can be $\mathrm{A} \rightarrow \mathrm{Y}$. The Quine-McCluskey algorithm is implemented for conducting the minimisation process (Ragin 2008).

\section{References}

Aktas, N., Croci, E., \& Petmezas, D. (2015). Is working capital management value-enhancing? Evidence from firm performance and investments. Journal of Corporate Finance, 30, 98-113.

Allison, P. D. (2009). Fixed effects regression models (Vol. 160). Thousand Oaks: SAGE Publications.

Almeida, H., Campello, M., \& Weisbach, M. S. (2004). The cash flow sensitivity of cash. Journal of Finance, 59(4), 1777-1804. https://doi.org/10.1111/j.1540-6261.2004.00679.x.

Altaf, N., \& Farooq, A. (2019). Working capital financing, firm performance and financial constraints. International Journal of Managerial Finance, 15(4), 464-477. https://doi.org/10.1108/ IJMF-02-2018-0036.

Altman, E. I. (1968). Financial ratios, discriminant analysis and the prediction of corporate bankruptcy. The Journal of Finance, 23(4), 589-609.

Altman, E. I. (2013). Predicting financial distress of companies: revisiting the Z-score and ZETA ${ }^{\circledR}$ models. In A. R. Bell, C. Brooks, \& M. Prokopczuk (Eds.), Handbook of research methods and applications in empirical finance. Cheltenham: Edward Elgar Publishing.

Alvarez, J., \& Arellano, M. (2003). The time series and cross-section asymptotics of dynamic panel data estimators. Econometrica, 71(4), 1121-1159.

Amr Ahmed, M. (2019). Determinants of working capital behavior: evidence from Egypt. International Journal of Managerial Finance, 15(1), 39-61. https://doi.org/10.1108/IJMF-09-2017-0219.

Arslan, Ö., Florackis, C., \& Ozkan, A. (2006). The role of cash holdings in reducing investment-cash flow sensitivity: Evidence from a financial crisis period in an emerging market. Emerging Markets Review, 7(4), 320-338.

Baños-Caballero, S., García-Teruel, P. J., \& Martínez-Solano, P. (2010). Working capital management in SMEs. Accounting \& Finance, 50(3), 511-527. https://doi.org/10.1111/j.1467-629X.2009.00331.x. 
Baños-Caballero, S., García-Teruel, P., \& Martínez-Solano, P. (2012). How does working capital management affect the profitability of Spanish SMEs? An Entrepreneurship Journal, 39(2), 517-529. https ://doi.org/10.1007/s11187-011-9317-8.

Baños-Caballero, S., García-Teruel, P. J., \& Martínez-Solano, P. (2014). Working capital management, corporate performance, and financial constraints. Journal of Business Research, 67(3), 332-338. https://doi.org/10.1016/j.jbusres.2013.01.016.

Baños-Caballero, S., García-Teruel, P. J., \& Martínez-Solano, P. (2016). Financing of working capital requirement, financial flexibility and SME performance. Journal of Business Economics and Management, 17(6), 1189-1204. https://doi.org/10.3846/16111699.2015.1081272.

Baños-Caballero, S., García-Teruel, P. J., \& Martínez-Solano, P. (2019). Net operating working capital and firm value: A cross-country analysis. BRQ Business Research Quarterly. https://doi. org/10.1016/j.brq.2019.03.003.

Bates, T. W., Chang, C.-H., \& Chi, J. D. (2018). Why has the value of cash increased over time? Journal of Financial and Quantitative Analysis, 53(2), 749-787. https://doi.org/10.1017/S00221090170011 $7 \mathrm{X}$.

Bates, T. W., Kahle, K. M., \& Stulz, R. M. (2009). Why do U.S. firms hold so much more cash than they used to? Journal of Finance, 64(5), 1985-2021. https://doi.org/10.1111/j.1540-6261.2009.01492.x.

Baumgartner, M. (2015). Parsimony and causality. Quality \& Quantity, 49(2), 839-856.

Bedford, D. S., \& Malmi, T. (2015). Configurations of control: An exploratory analysis. Management Accounting Research, 27, 2-26.

Bedford, D. S., Malmi, T., \& Sandelin, M. (2016). Management control effectiveness and strategy: An empirical analysis of packages and systems. Accounting, Organizations and Society, 51(C), 12-28. https://doi.org/10.1016/j.aos.2016.04.002.

Bedford, D. S., \& Sandelin, M. (2015). Investigating management control configurations using qualitative comparative analysis: An overview and guidelines for application. Journal of Management Control, 26(1), 5-26. https://doi.org/10.1007/s00187-015-0204-3.

Bertrand, M., \& Mullainathan, S. (2003). Enjoying the quiet life? Corporate governance and managerial preferences. Journal of Political Economy, 111(5), 1043-1075.

Biais, B., \& Gollier, C. (1997). Trade credit and credit rationing. The Review of Financial Studies, 10(4), 903-937.

Bun, M. J., Carree, M. A., \& Juodis, A. (2017). On maximum likelihood estimation of dynamic panel data models. Oxford Bulletin of Economics and Statistics, 79(4), 463-494.

Byoun, S. (2011). Financial flexibility and capital structure decision. Available at SSRN 1108850.

Chenhall, R. H. (2003). Management control systems design within its organizational context: Findings from contingency-based research and directions for the future. Accounting, Organizations and Society, 28(2-3), 127-168. https://doi.org/10.1016/S0361-3682(01)00027-7.

Chenhall, R. H., \& Moers, F. (2007). The issue of endogeneity within theory-based, quantitative management accounting research. European Accounting Review, 16(1), 173-196. https://doi. org/10.1080/09638180701265937.

Combs, J. G., Crook, T. R., \& Shook, C. L. (2005). The dimensionality of organizational performance and its implications for strategic management research. Research Methodology in Strategy and Management, 2(5), 259-286.

Cuñat, V., \& Garcia-Appendini, E. (2012). Trade credit and its role in entrepreneurial finance. In D. Cumming (Ed.), Oxford handbook of entrepreneurial finance (pp. 526-557). New York: Oxford University Press.

Deloof, M. (2003). Does working capital management affect profitability of Belgian firms? Journal of Business Finance \& Accounting, 30(3-4), 573-588. https://doi.org/10.1111/1468-5957.00008.

Demiroglu, C., \& James, C. (2011). The use of bank lines of credit in corporate liquidity management: A review of empirical evidence. Journal of Banking \& Finance, 35(4), 775-782.

Dul, J. (2016). Identifying single necessary conditions with NCA and fsQCA. Journal of Business Research, 69(4), 1516-1523. https://doi.org/10.1016/j.jbusres.2015.10.134.

Enqvist, J., Graham, M., \& Nikkinen, J. (2014). The impact of working capital management on firm profitability in different business cycles: Evidence from Finland. Research in International Business and Finance, 32(C), 36-49. https://doi.org/10.1016/j.ribaf.2014.03.005.

Eroglu, C., \& Hofer, C. (2011). Lean, leaner, too lean? The inventory-performance link revisited. Journal of Operations Management, 29(4), 356-369. https://doi.org/10.1016/j.jom.2010.05.002.

Fabbri, D., \& Menichini, A. M. C. (2010). Trade credit, collateral liquidation, and borrowing constraints. Journal of Financial Economics, 96(3), 413-432. 
Faden, C. (2014). Optimizing firm performance: Alignment of operational success drivers on the basis of empirical data. Wiesbaden: Springer.

Faulkender, M. W., Hankins, K. W., \& Petersen, M. A. (2019). Understanding the rise in corporate cash: Precautionary savings or foreign taxes. The Review of Financial Studies, 32(9), 3299-3334.

Faulkender, M., \& Wang, R. (2006). Corporate financial policy and the value of cash. Journal of Finance, 61(4), 1957-1990. https://doi.org/10.1111/j.1540-6261.2006.00894.x.

Fazzari, S. M., Hubbard, R. G., Petersen, B. C., Blinder, A. S., \& Poterba, J. M. (1988). Financing constraints and corporate investment. Brookings Papers on Economic Activity, 1988(1), 141-206. https ://doi.org/10.2307/2534426.

Fazzari, S. M., \& Petersen, B. C. (1993). Working capital and fixed investment: New evidence on financing constraints. The Rand Journal of Economics, 24(3), 328-342. https://doi.org/10.2307/2555961.

Fischer, H. M., \& Pollock, T. G. (2004). Effects of social capital and power on surviving transformational change: The case of initial public offerings. Academy of Management Journal, 47(4), 463-481.

Fiss, P. C. (2011). Building better causal theories: A fuzzy set approach to typologies in organization research. The Academy of Management Journal, 54(2), 393-420. https://doi.org/10.5465/ AMJ.2011.60263120.

Fiss, P. C., Marx, A., \& Cambré, B. (2013a). Chapter 1 configurational theory and methods in organizational research: Introduction. In P. C. Fiss, B. Cambré, \& A. Marx (Eds.), Configurational theory and methods in organizational research (pp. 1-22). Bingley: Emerald Group Publishing Limited.

Fiss, P. C., Sharapov, D., \& Cronqvist, L. (2013b). Opposites attract? Opportunities and challenges for integrating large-N QCA and econometric analysis. Political Research Quarterly, 66(1), 191-198. https://doi.org/10.1177/1065912912468269e.

Fresard, L. (2010). Financial strength and product market behavior: The real effects of corporate cash holdings. Journal of Finance, 65(3), 1097-1122. https://doi.org/10.1111/j.1540-6261.2010.01562 .X.

Galeazzo, A., \& Furlan, A. (2018). Lean bundles and configurations: A fsQCA approach. International Journal of Operations \& Production Management, 38(2), 513-533. https://doi.org/10.1108/IJOPM -11-2016-0657.

Gama, P., \& Pais, M. (2015). Working capital management and SMEs profitability: Portuguese evidence. International Journal of Managerial Finance, 11(3), 341-358. https://doi.org/10.1108/ IJMF-11-2014-0170.

Gamba, A., \& Triantis, A. (2008). The value of financial flexibility. Journal of Finance, 63(5), 22632296. https://doi.org/10.1111/j.1540-6261.2008.01397.x.

García-Teruel, P., \& Martínez-Solano, P. (2007). Effects of working capital management on SME profitability. International Journal of Managerial Finance, 3(2), 164-177. https://doi.org/10.1108/17439 130710738718.

García-Teruel, P. J., \& Martínez-Solano, P. (2010). A dynamic approach to accounts receivable: A study of Spanish SME s. European Financial Management, 16(3), 400-421. https://doi.org/10.1111/ j.1468-036X.2008.00461.x.

Gatev, E., \& Strahan, P. E. (2006). Banks' advantage in hedging liquidity risk: Theory and evidence from the commercial paper market. The Journal of Finance, 61(2), 867-892.

Gerdin, J., \& Greve, J. (2004). Forms of contingency fit in management accounting research-A critical review. Accounting, Organizations and Society, 29(3-4), 303-326.

Gerdin, J., \& Greve, J. (2008). The appropriateness of statistical methods for testing contingency hypotheses in management accounting research. Accounting, Organizations and Society, 33(7-8), 995-1009.

Gill, A., Biger, N., \& Mathur, N. (2010). The relationship between working capital management and profitability: Evidence from the United States. Business and Economics Journal, 10(1), 1-9.

Gitman, L. J. J. F. R. (1974). Estimating corporate liquidity requirements: A simplified approach. The Financial Review, 9(1), 79-88.

Grabner, I., \& Moers, F. (2013). Management control as a system or a package? Conceptual and empirical issues. Accounting, Organizations and Society, 38(6-7), 407-419. https://doi.org/10.1016/j. aos.2013.09.002.

Granlund, M., \& Lukka, K. (2017). Investigating highly established research paradigms: Reviving contextuality in contingency theory based management accounting research. Critical Perspectives on Accounting, 45, 63-80. 
Greckhamer, T., Furnari, S., Fiss, P. C., \& Aguilera, R. V. (2018). Studying configurations with qualitative comparative analysis: Best practices in strategy and organization research. Strategic Organization, 16(4), 482-495.

Greckhamer, T., Misangyi, V. F., \& Fiss, P. C. (2013). Chapter 3 The two QCAs: From a small-N to a large-N set theoretic approach. In P. C. Fiss, B. Cambré, \& A. Marx (Eds.), Configurational theory and methods in organizational research (pp. 49-75). Bingley: Emerald Group Publishing Limited.

Grofman, B., \& Schneider, C. Q. (2009). An introduction to crisp set QCA, with a comparison to binary logistic regression. Political Research Quarterly, 62(4), 662-672.

Guenther, T. W., Riehl, A., \& Rößler, R. (2014). Cost stickiness: State of the art of research and implications. Journal of Management Control, 24(4), 301-318.

Hair, J. F., Black, W. C., \& Babin, B. J. (2013). Multivariate data analysis: Pearson new international edition. London: Pearson Education Limited.

Hallahan, A. T., \& Faff, R. W. (2001). Induced persistence or reversals in fund performance?: The effect of survivorship bias. Applied Financial Economics, 11(2), 119-126. https://doi.org/10.1080/09603 1001750071505.

Hamann, P. M., Schiemann, F., Bellora, L., \& Guenther, T. W. (2013). Exploring the dimensions of organizational performance: A construct validity study. Organizational Research Methods, 16(1), 67-87. https://doi.org/10.1177/1094428112470007.

Han, S., \& Qiu, J. (2007). Corporate precautionary cash holdings. Journal of Corporate Finance, 13(1), 43-57. https://doi.org/10.1016/j.jcorpfin.2006.05.002.

Ho, J., Plewa, C., \& Lu, V. N. (2016). Examining strategic orientation complementarity using multiple regression analysis and fuzzy set QCA. Journal of Business Research, 69(6), 2199-2205.

Howorth, C., \& Westhead, P. (2003). The focus of working capital management in UK small firms. Management Accounting Research, 14(2), 94-111. https://doi.org/10.1016/S1044-5005(03)00022-2.

Huang, C.-W., \& Huarng, K.-H. (2015). Evaluating the performance of biotechnology companies by causal recipes. Journal of Business Research, 68(4), 851-856.

Huber, P.J. (1967). The behavior of maximum likelihood estimates under nonstandard conditions. In Proceedings of the fifth Berkeley symposium on mathematical statistics and probability (Vol. 1, No. 1, pp. 221-233).

Huson, M., \& Nanda, D. (1995). The impact of just-in-time manufacturing on firm performance in the US. Journal of Operations Management, 12(3-4), 297-310.

Jain, N. (2001). Monitoring costs and trade credit. The Quarterly Review of Economics and Finance, 41(1), 89-110.

Jensen, M. C. (1986). Agency costs of free cash flow, corporate finance, and takeovers. The American Economic Review, 76(2), 323-329. https://doi.org/10.2307/1818789.

Karatzas, A., Johnson, M., \& Bastl, M. (2016). Relationship determinants of performance in service triads: A configurational approach. Journal of Supply Chain Management, 52(3), 28-47. https://doi. org/10.1111/jscm.12109.

Kim, C., \& Bettis, R. A. (2014). Cash is surprisingly valuable as a strategic asset. Strategic Management Journal, 35(13), 2053-2063. https://doi.org/10.1002/smj.2205.

Kling, G., Paul, S. Y., \& Gonis, E. (2014). Cash holding, trade credit and access to short-term bank finance. International Review of Financial Analysis, 32, 123-131. https://doi.org/10.1016/j. irfa.2014.01.013

Kosmol, T., Reimann, F., \& Kaufmann, L. (2018). Co-alignment of supplier quality management practices and cognitive maps-A neo-configurational perspective. Journal of Purchasing and Supply Management, 24(1), 1-20. https://doi.org/10.1016/j.pursup.2017.11.002.

Kroes, J. R., \& Manikas, A. S. (2014). Cash flow management and manufacturing firm financial performance: A longitudinal perspective. International Journal of Production Economics, 148(C), 37-50. https://doi.org/10.1016/j.ijpe.2013.11.008.

Larcker, D. F., \& Rusticus, T. O. (2010). On the use of instrumental variables in accounting research. Journal of Accounting and Economics, 49(3), 186-205. https://doi.org/10.1016/j.jacce co.2009.11.004.

Lyngstadaas, H., \& Berg, T. (2016). Working capital management: Evidence from Norway. International Journal of Managerial Finance, 12(3), 295-313.

Malmi, T., \& Brown, D. A. (2008). Management control systems as a package-Opportunities, challenges and research directions. Management Accounting Research, 19(4), 287-300. https://doi. org/10.1016/j.mar.2008.09.003. 
Martínez-Sola, C., García-Teruel, P. J., \& Martínez-Solano, P. (2013). Trade credit policy and firm value. Accounting \& Finance, 53(3), 791-808. https://doi.org/10.1111/j.1467-629X.2012.00488.x.

Martínez-Sola, C., García-Teruel, P., \& Martínez-Solano, P. (2014). Trade credit and SME profitability. An Entrepreneurship Journal, 42(3), 561-577. https://doi.org/10.1007/s11187-013-9491-y.

Martínez-Sola, C., García-Teruel, P., \& Martínez-Solano, P. (2018). Cash holdings in SMEs: Speed of adjustment, growth and financing. An Entrepreneurship Journal, 51(4), 823-842. https://doi. org/10.1007/s11187-018-9990-y.

Maurizio La, R. (2019). The effect of cash holdings on firm performance in large Italian companies. Journal of International Financial Management \& Accounting, 30(1), 30-59. https://doi.org/10.1111/ jifm.12090.

Meltzer, A. H. (1960). Mercantile credit, monetary policy, and size of firms. The review of Economics and Statistics, 42(4), 429-437.

Meuer, J., \& Rupietta, C. (2017). A review of integrated QCA and statistical analyses. Quality \& Quantity, 51(5), 2063-2083.

Misangyi, V. F., \& Acharya, A. G. (2014). Substitutes or complements? A configurational examination of corporate governance mechanisms. Academy of Management Journal, 57(6), 1681-1705.

Mun, S. G., \& Jang, S. (2015). Working capital, cash holding, and profitability of restaurant firms. International Journal of Hospitality Management, 48, 1-11. https://doi.org/10.1016/j.ijhm.2015.04.003.

Nason, R. S., \& Patel, P. C. (2016). Is cash king? Market performance and cash during a recession. Journal of Business Research, 69(10), 4242-4248. https://doi.org/10.1016/j.jbusres.2016.03.001.

Neumayer, E., \& Plümper, T. (2017). Robustness tests for quantitative research. Cambridge: Cambridge University Press.

Ng, C. K., Smith, J. K., \& Smith, R. L. (1999). Evidence on the Determinants Of Credit Terms Used In Interfirm Trade. Journal of Finance, 54(3), 1109-1129. https://doi.org/10.1111/0022-1082.00138.

Nickell, S. (1981). Biases in dynamic models with fixed effects. Econometrica: Journal of the Econometric Society, 49(6), 1417-1426.

Opler, T., Pinkowitz, L., Stulz, R., \& Williamson, R. (1999). The determinants and implications of corporate cash holdings. Journal of Financial Economics, 52(1), 3-46. https://doi.org/10.1016/S0304 -405X(99)00003-3.

Ordanini, A., Parasuraman, A., \& Rubera, G. (2014). When the recipe is more important than the ingredients: A qualitative comparative analysis (QCA) of service innovation configurations. Journal of Service Research, 17(2), 134-149.

Osisioma, B. (1997). Sources and management of working capital. Journal of Management Sciences, 2 , 21-26.

Otley, D. (2016). The contingency theory of management accounting and control: 1980-2014. Management Accounting Research, 31(C), 45-62. https://doi.org/10.1016/j.mar.2016.02.001.

Picconi, M., \& Oler, D. (2014). Implications of insufficient and excess cash for future perfomance. Contemporary Accounting Research, 31(1), 253-282.

Ragin, C. C. (2000). Fuzzy-set social science. Chicago: University of Chicago Press.

Ragin, C. C. (2006a). The limitations of net-effects thinking. Innovative comparative methods for policy analysis (pp. 13-41). Boston: Springer.

Ragin, C. C. (2006b). Set relations in social research: Evaluating their consistency and coverage. Political Analysis, 14(3), 291-310.

Ragin, C. C. (2008). Redesigning social inquiry: Fuzzy sets and beyond. Chicago: University of Chicago Press.

Ragin, C. C. (2014). The comparative method: Moving beyond qualitative and quantitative strategies. Berkeley: University of California Press.

Ragin, C. C., \& Rihoux, B. (2009). Configurational comparative methods: Qualitative comparative analysis (QCA) and related techniques (Vol. 51). Thousand Oaks: Sage.

Richardson, S. (2006). Over-investment of free cash flow. Review of Accounting Studies, 11(2-3), 159-189.

Rihoux, B. (2006). Qualitative comparative analysis (QCA) and related systematic comparative methods: Recent advances and remaining challenges for social science research. International Sociology, 21(5), 679-706.

Schneider, C. Q., \& Wagemann, C. (2010). Standards of good practice in qualitative comparative analysis (QCA) and fuzzy-sets. Comparative Sociology, 9(3), 397-418.

Siggelkow, N. (2002). Evolution toward fit. Administrative Science Quarterly, 47(1), 125-159. https://doi. org/10.2307/3094893. 
Talonpoika, A.-M., Kärri, T., Pirttilä, M., \& Monto, S. (2016). Defined strategies for financial working capital management. International Journal of Managerial Finance, 12(3), 277-294. https://doi. org/10.1108/IJMF-11-2014-0178.

Van Lent, L. (2007). Endogeneity in management accounting research: A comment. European Accounting Review, 16(1), 197-205. https://doi.org/10.1080/09638180701269863.

Venkiteshwaran, V. (2011). Partial adjustment toward optimal cash holding levels. Review of Financial Economics, 20(3), 113-121. https://doi.org/10.1016/j.rfe.2011.06.002.

Vis, B. (2012). The comparative advantages of fsQCA and regression analysis for moderately large- $\mathrm{N}$ analyses. Sociological Methods \& Research, 41(1), 168-198.

Wagemann, C., Buche, J., \& Siewert, M. B. (2016). QCA and business research: Work in progress or a consolidated agenda? Journal of Business Research, 69(7), 2531-2540. https://doi.org/10.1016/j. jbusres.2015.10.010.

Weinraub, H. J., \& Visscher, S. (1998). Industry practice relating to aggressive conservative working capital policies. Journal of Financial and Strategic Decision, 11(2), 11-18.

White, H. (1980). A heteroskedasticity-consistent covariance matrix estimator and a direct test for heteroskedasticity. Econometrica, 48(4), 817. https://doi.org/10.2307/1912934.

Wilner, B. S. (2000). The exploitation of relationships in financial distress: The case of trade credit. The Journal of Finance, 55(1), 153-178.

Womack, J. P., \& Jones, D. T. (2003). Lean thinking: Banish waste and create wealth in your corporation. Riverside: Free Press.

Woodside, A. G. (2013). Moving beyond multiple regression analysis to algorithms: Calling for adoption of a paradigm shift from symmetric to asymmetric thinking in data analysis and crafting theory. Journal of Business Research, 66(4), 463-472.

Zaefarian, G., Kadile, V., Henneberg, S. C., \& Leischnig, A. (2017). Endogeneity bias in marketing research: Problem, causes and remedies. Industrial Marketing Management, 65, 39-46. https://doi. org/10.1016/j.indmarman.2017.05.006.

Zeidan, R., \& Shapir, O. M. (2017). Cash conversion cycle and value-enhancing operations: Theory and evidence for a free lunch. Journal of Corporate Finance, 45, 203-219.

Publisher's Note Springer Nature remains neutral with regard to jurisdictional claims in published maps and institutional affiliations. 